\title{
Heterogeneity of Trypanosoma cruzi infection rates in vectors and animal reservoirs in Colombia: a systematic review and meta-analysis
}

\author{
Eliana Rodríguez-Monguí ', Omar Cantillo-Barraza², Franklin Edwin Prieto-Alvarado ${ }^{1}$ (1) \\ and Zulma M. Cucunubá ${ }^{3 *}$ (B)
}

\begin{abstract}
Background: The heterogeneity of Trypanosoma cruzi infection rates among triatomines insects and animal reservoirs has been studied in independent studies, but little information has been systematised to allow pooled and comparative estimates. Unravelling the main patterns of this heterogeneity could contribute to a further understanding of T. cruzi transmission in Colombia.

Methods: A systematic search was conducted in PubMed, Medline, LILACS, Embase, Web of Knowledge, Google Scholar and secondary sources with no filters of language or time and until April 2018. Based on selection criteria, all relevant studies reporting T. cruzi infection rates in reservoirs or triatomines were chosen. For pooled analyses, a random effects model for binomial distribution was used. Heterogeneity among studies is reported as $P^{2}$. Subgroup analyses included: taxonomic classification, ecotope and diagnostic methods. Publication bias and sensitivity analyses were performed.
\end{abstract}

Results: Overall, 39 studies reporting infection rates in Colombia were found ( 22 for potential reservoirs and 28 for triatomine insects) for a total sample of 22,838 potential animals and 11,307 triatomines evaluated for T. cruzi infection. We have found evidence of 38/71 different animal species as potential T. cruzi reservoirs and 14/18 species as triatomine vectors for T. cruzi. Among animals, the species with the highest pooled prevalence were opossum (Didelphis marsupialis) with $48.0 \%\left(95 \% \mathrm{Cl}: 26-71 \% ; I^{2}=88 \%, \tau^{2}=0.07, P<0.01\right)$ and domestic dog (Canis lupus familiaris) with $22.0 \%$ (95\% Cl: $4-48 \% ; P^{2}=96 \%, T^{2}=0.01, P<0.01$ ). Among triatomines, the highest prevalence was found for Triatoma maculata in the peridomestic ecotope $\left(68.0 \%, 95 \% \mathrm{Cl}: 62-74 \% ; P^{2}=0 \%, T^{2}=0, P<0.0001\right)$, followed by Rhodnius prolixus $\left(62.0 \%, 95 \% \mathrm{Cl}: 38-84 \% ; P^{2}=95 \%, T^{2}=0.05, P<0.01\right)$ and Rhodnius pallescens $\left(54.0 \%, 95 \% \mathrm{Cl}: 37-71 \% ; P^{2}=86 \%\right.$, $\left.T^{2}=0.035, P<0.01\right)$ in the sylvatic ecotope.

Conclusions: To our knowledge, this is the first systematic and quantitative analyses of triatomine insects and potential animal reservoirs for T. cruzi infection in Colombia. The results highlight a marked heterogeneity between species and provide initial estimates of infection rates heterogeneity.

Keywords: Chagas disease, Trypanosoma cruzi, Triatomines, Reservoirs, Infection rates, Heterogeneity

\footnotetext{
*Correspondence: zulma.cucunuba@imperial.ac.uk

${ }^{3}$ Department of Infectious Disease Epidemiology, MRC Centre for Global Infectious Disease Analysis (MRC GIDA), Imperial College London, London, UK

Full list of author information is available at the end of the article
} 


\section{Background}

Chagas disease is caused by the protozoan Trypanosoma cruzi, a parasite largely distributed across 21 Latin American countries where it has been associated with increased morbidity and mortality and a high economic burden $[1,2]$. Transmission through triatomine vectors is the most frequent route, followed in frequency by congenital, blood transfusions, transplants and oral mechanisms [3].

Trypanosoma cruzi transmission is highly complex as it is the cause of a zoonotic parasitosis present in more than 150 animal reservoirs and 147 triatomine vectors [4, 5]. Additionally, six different discreet typing units (DTUs) of $T$. cruzi have been described so far $[4,6,7]$. The role that different animals and triatomine species play in $T$. cruzi transmission to humans depends on the local conditions that facilitate contact with humans in the different type of cycles: sylvatic, peridomestic and domestic [8]. Importantly, domestic transmission from non-native triatomines is subject to control via insecticide spraying and housing improvement, and there has been a great success controlling these vectors across Latin American countries [9-11]. However, sylvatic transmission is much more complex and control measures are less clear [12]; continued population growth and deforestation across sylvatic areas increase the likelihood that humans establish closer contact with both animal reservoirs and triatomine vectors from the sylvatic cycles [8]. Furthermore, there is an increased report of outbreaks arising from oral transmission in both rural areas and major urban populations of Brazil, Colombia and Venezuela, also suggesting an increased contact between sylvatic and domestic ecotopes [13].

Among sylvatic mammals, the most frequently reported species associated to $T$. cruzi transmission are from the order Didelphimorphia, and particularly the species Didelphis marsupialis [14-17]. These animals are considered transmission amplifiers due to their generally high parasitaemia and easy adaptation to disturbed areas [18]. Other sylvatic orders with species reported as hosts include Cingulata (Dasypus novencintus), Rodentia (Akodon spp., Dasyprocta spp.), Chiroptera (Carollia perspicillata, Artibeus fuliginosus) and primates (Ateles spp., Cebus spp.) [7]. Among domestic mammals, the species of the orders Carnivora (Canis lupus familiaris, Felis silvestris catus) and Rodentia (Rattus rattus, Rattus norvegicus and Cavia spp.) have been reported with high infection rates, whereas large mammals from the orders Artiodactyla (subfamilies Bovinae, Caprinae and Suinae) and Perissodactyla (family Equidae) are rarely infected or show very low infection rates in South America [7].

In Colombia, 26 triatomine species have been reported as potential vectors for T. cruzi. Among them, Rhodnius prolixus, Triatoma dimidiata, T. maculata and $T$. venosa are the most frequently found close to humans, within houses or in the surrounding area (peridomicile) $[6,19]$. However, a large number of sylvatic species have the capacity to occasionally invade homes and to lead to human infection. The importance of these species is indicated by their distribution, density, transmission efficiency, feeding behaviour and the prevalence of infection $[20,21]$. The main triatomine species in domiciliated habitats in Colombia is $R$. prolixus. Important efforts to interrupt domestic transmission from this species to humans have been made in the last decades and great progress has been made in some parts of the country [22]. However, Chagas outbreaks resulting from oral transmission have been continuously reported in recent decades, highlighting the importance of gaining a better understanding of the sylvatic cycle [16].

Documenting and quantifying general trends and heterogeneity in infection rates among the different reservoir hosts and triatomine vector species is paramount to understanding the role that these species play in T. cruzi transmission to humans. Here, we conducted a literature review and meta-analysis of the existent evidence for $T$. cruzi presence and infection rates in vectors and animal reservoirs in Colombia.

\section{Methods}

The systematic review and meta-analysis were carried out following the verification checklist PRISMA to ensure standardised methods (Additional file 1).

\section{Search strategy}

A search for observational studies of $T$. cruzi infection among animal reservoirs and triatomine vectors was conducted in PubMed, Medline, Index Medicus, LILACS, Embase and Web of Knowledge without language or time filter until 5th April 2018. Additionally, a secondary search through Google Scholar and Colombia University thesis repositories was conducted. For details of the search algorithm, see Additional file 2: Table S1.

\section{Selection criteria and data extraction}

Selection criteria included: (i) study type as cross-sectional studies that included triatomines or potential animal reservoirs; (ii) conduced in Colombian territory; (iii) reporting details of the number of tested individuals and the number of positive individuals; (iv) with details on diagnostic method, ecotope of capture; (v) with a minimum sample size of 10 subjects for pooled calculations.

An Excel spreadsheet was used to report characteristics of the studies, including reference, year of the study, place, ecotope, sample size, diagnostic method and taxonomic classification. For quantitative analyses, both 
triatomines and potential animal reservoirs were grouped by taxonomic characteristics (order, family, genus and species) as much as possible.

Diagnostic methods for potential reservoirs were classified as: (i) serological methods that do not account for current infection and have high cross-reactivity with other tripanosomatid species; (ii) non-serological methods, including both parasitological (blood spread smear, hemoculture and xenodiagnostic) and molecular methods (PCR), that allow establishing solid evidence as $T$. cruzi reservoirs; and (iii) mixed methods, which use a combination of the two previous methods but with no clear information to allow disaggregated data.

Diagnostic methods for triatomine vectors were classified as: (i) T. cruzi species-specific (PCR, culture and mice inoculation); and (ii) T. cruzi non-species-specific (i.e. microscopic examination of extruded faeces), as $T$. rangeli or other flagellates such as Crithidia could confound diagnostic [23-25].

\section{Quality assessment}

A content quality assessment was conducted. The items evaluated included research question, sampling method, study period, diagnostic method, and potential bias. We allocated a score to each item in order to create an overall classification of high, moderate, or low quality [26] (see Additional file 2: Figure S1).

\section{Statistical analysis \\ Descriptive statistics}

Descriptive statistics are presented as proportion of infection and 95\% confidence intervals (95\% CI). Frequency tables and maps of geographical distribution are presented.

\section{Pooled analysis}

A meta-analysis of binary outcome with binomial distribution was conducted in $\mathrm{R}$ v.3.2.2. specifically using the 'meta' library [27]. In order to stabilise variance a Freeman-Tukey double-arccosine transformation was used $[27,28]$. Given the fact that the study design used for the multiple species, the sample size, geographical characteristics and methods used could differ between studies, a random effects model was considered more appropriate [29], where tau-squared $\left(\tau^{2}\right)$ represents the variance between studies [27, 29]. For assessing heterogeneity between studies, the $I^{2}$ - and Cochran's $\mathrm{Q}$ tests are presented. $I^{2}$ indicates the proportion of the total variation attributed to heterogeneity, i.e. an assessment of the degree of coherence between studies $\left[I^{2}=100 \% \times(\mathrm{Q}-\mathrm{df}) / \mathrm{Q}\right]$. The Cochran's $\mathrm{Q}$ is calculated as the sum of the squared deviations of each study's estimate that allows weighting each study's contribution [30].

\section{Publication bias and sensitivity analysis}

Publication bias was assessed when possible (for metaanalysis with at least five studies included), by using the Egger's test, funnel plots and Trim fill technique evaluating the potential effect of non-included studies on the general estimates [31]. Sensitivity analysis was conducted by re-assessing general effect while sequentially omitting one study at a time [32] and also restricting the analyses to only high quality studies.

\section{Results}

\section{General findings}

Overall, 960 potentially useful studies were found. After reading all abstracts and based on the selection criteria indicated above, 40 studies containing relevant information of the presence of $T$. cruzi infection in animals or triatomines were selected, including one study on culture parasite isolates [33] that was relevant for qualitative analyses but not for prevalence calculations. Therefore, for prevalence calculations we used 39 studies; of these, 22 included data for prevalence in potential animal reservoir and 28 for prevalence in triatomine vectors (see Fig. 1 for details). Table 1 shows a general description of the final 39 studies included in the quantitative analyses.

Geographical distribution of the samples used in the studies for potential animal reservoirs and triatomine vectors include 9 and 16 departments (first administrative level), respectively, and also the special territory of the Sierra Nevada de Santa Marta (SNSM). The departments with the highest number of studies were Casanare, Córdoba, Meta and Bolívar for reservoirs and Casanare, Bolívar, César, Guajira, Magdalena and SNSM for triatomines (see Fig. 2) (for details, see Additional file 2: Table S2.

\section{Potential reservoirs}

The number of subjects (potential animal reservoirs) analysed in the 22 selected studies was 22,838 of which 1585 (6.94\%) were found infected with Trypanosoma spp. Eighteen of these studies reported the capture method; Sherman ${ }^{\circledR}$ and Tomahawak ${ }^{\circledR}$ were the most commonly used. All 22 studies reported the ecotope of collection and diagnostic method. The geographical distribution of the studies included classified by taxonomic order are shown in Fig. 3. Overall, 71 animal species of nine mammal orders were studied, out of which 38 were found infected with T. cruzi (Table 2).

The geographical distribution of potential animal reservoirs and proportion of infection found by location by taxonomic order are presented in Fig. 4. Further details on the general characteristics of the studies and 


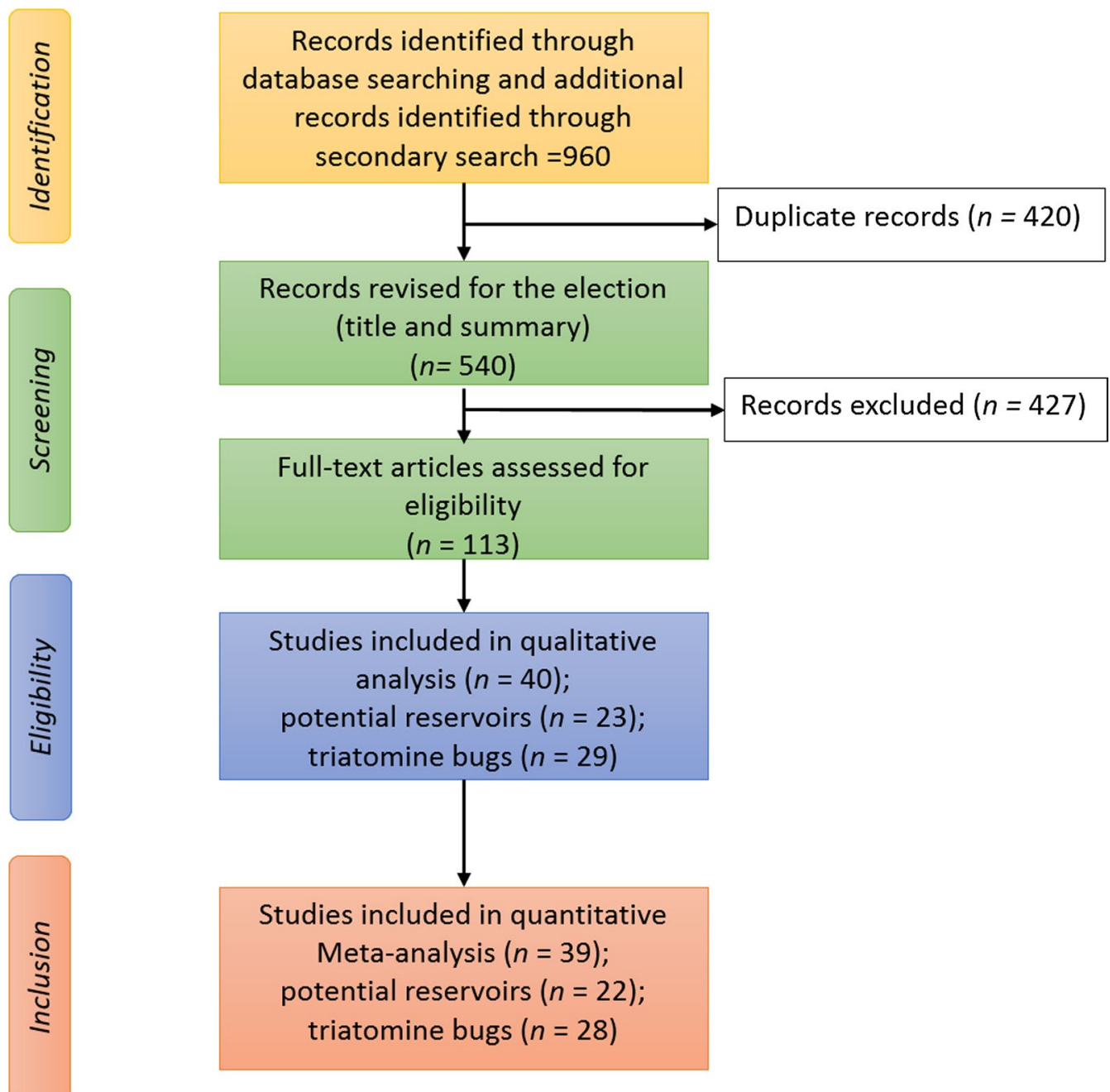

Fig. 1 Flow diagram describing the search and selection process for both qualitative and quantitative analysis

proportion of infection are shown in Additional file 2: Table S3.

\section{Triatomine insects}

The total sample size among studies included was 11,307 triatomines of which 1721 (15.22\%) presented Trypanosoma spp. infection; of these, 1354 (11.97\%) presented infection by $T$. cruzi. The capture protocols most commonly used were active search and live bait traps. Out of the 28 studies, 23 registered disaggregated data for ecotope of collection. Diagnostic methods used were mainly parasitological (direct microscopic examination of extruded faeces) followed by PCR and mice inoculation (see Additional file 2: Table S4) for further details.

In the selected papers, 18 triatomine species were studied of which four (Belminus ferroae, Eratyrus mucronatus, Psammolestes arthuri and Panstrongylus lignarius) were found with no evidence and 14 with solid evidence of T. cruzi infection (Table 3). Table 3 shows the geographical distribution of all triatomine species studied, except for Triatoma dispar, Rhodnius robustus and $R$. colombiensis as the studies reporting these species did not have geographical information. The point prevalence of Trypanosoma spp. in triatomine insects and the geographical distribution is presented in Fig. 5.

\section{Pooled analyses}

Pooled prevalence of $T$. cruzi infection in animal reservoirs

Out of the nine orders of potential reservoirs reported in this study, seven presented sufficient sample size and additional information for calculating pooled estimates of the prevalence of T. cruzi infection. The aggregated estimates showed that the species with highest prevalence was Didelphis marsupialis, followed by Canis familiaris (Table 4). Further details of the disaggregated results are shown in Additional file 2: Table S5. 
Table 1 General information on the 39 studies included for quantitative analysis of T. cruzi infection in potential animal reservoirs and triatomine vectors

\begin{tabular}{|c|c|c|c|c|c|}
\hline References & Study period & Department & No. mun $(n)$ & $\begin{array}{l}\text { Triatomine } \\
\text { bugs }(n)\end{array}$ & $\begin{array}{l}\text { Potential } \\
\text { reservoirs } \\
(n)\end{array}$ \\
\hline Wolff et al. 2001 [79] & 1997-1999 & Antioquia & 8 & 124 & 70 \\
\hline Escalante et al. 2015 [80] & 2013 & Atlántico, Bolívar, Córdoba, Sucre & 4 & 89 & 0 \\
\hline Parra-Henao et al. 2015 [81] & $2002-2014$ & Atlántico, Boyacá, Caquetá, Guajira & 77 & 4943 & 0 \\
\hline Cortéz et al. 2005 [82] & 2003 & Bolívar & 1 & 30 & 0 \\
\hline Cantillo-Barraza et al. 2010 [63] & 2006-2008 & Bolívar & 6 & 43 & 0 \\
\hline Cantillo-Barraza et al. 2015 [61] & 2010-2012 & Bolívar & 5 & 113 & 267 \\
\hline Vásquez et al. 2013 [77] & $2003-2004$ & Bolívar, Magdalena & 6 & 66 & 115 \\
\hline Manrique et al. 2012 [83] & 2009 & Boyacá & 2 & 0 & 60 \\
\hline Ramírez et al. 2013 [84] & 2012 & Boyacá & 2 & 0 & 80 \\
\hline Ramírez et al. 2014 [85] & 2010 & Casanare & 6 & 0 & 175 \\
\hline Rendón et al. 2015 [51] & 2012 & Casanare & 2 & 269 & 177 \\
\hline Urbano et al. 2015 [59] & 2012 & Casanare & 1 & 169 & 0 \\
\hline Jácome-Pinilla et al. 2015 [65] & 2012 & Casanare & 1 & 26 & 0 \\
\hline Angulo-Silva et al. 2016 [46] & 2008 & Casanare & 2 & 56 & 35 \\
\hline Zuleta-Dueñas et al. 2017 [38] & 2014 & Casanare & 1 & 0 & 4 \\
\hline Angulo et al. 2012 [58] & $2003-2006$ & Casanare, Arauca & 4 & 113 & 0 \\
\hline D’Alessandro 1971 [86] & 1968 & Casanare, Vichada, Meta & 3 & 0 & 11 \\
\hline Sandoval et al. 2004 [87] & 2001 & Cesar & 2 & 44 & 0 \\
\hline Montilla et al. 2011 [88] & $2006-2007$ & Cesar & 19 & 3107 & 0 \\
\hline Soto et al. 2014 [37] & 2010 & Cesar & 1 & 135 & 2 \\
\hline Parra et al. 2004 [89] & 1999 & Cesar, Guajira, Magdalena & $2(\mathrm{~V})$ SNSM & 70 & 1 \\
\hline Parra-Henao et al. 2009 [90] & $2006-2008$ & Cesar, Guajira, Magdalena & $8(V)$ & 207 & 0 \\
\hline Mejía-Jaramillo et al. 2014 [91] & 2011 & Cesar, Guajira, Magdalena & $4(\mathrm{~V})$ SNSM & 463 & 151 \\
\hline Parra-Henao et al. 2016 [92] & $2007-2008$ & Cesar, Guajira, Magdalena & 18 & 225 & 0 \\
\hline Marinkelle 1982(a) [93] & $1961-1972$ & Colombia & NM & 0 & 343 \\
\hline Marinkelle 1982(b) [50] & 1961-1972 & Colombia & $658(L)$ & 0 & 19885 \\
\hline Delgado-Sarmiento et al. 2016 [94] & 2013 & Córdoba & $4(L)$ & 0 & 30 \\
\hline Peña-García et al. 2014 [95] & 2010-2011 & Guajira & 1 & 78 & 12 \\
\hline Gómez-Melendro et al. 2014 [60] & 2013 & Guajira & 2 & 32 & 0 \\
\hline Cantillo-Barraza et al. 2014 [66] & 2011 & Isla Margarita & 5 & 0 & 27 \\
\hline Dib 2009 [96] & 2006 & Magdalena & 1 & 35 & 0 \\
\hline Salazar et al. 2003 [97] & 2003 & Magdalena & $7(\mathrm{~V})$ & 73 & 0 \\
\hline D’Alessandro et al. 1984 [71] & 1978-1979 & Meta & 2 & 384 & 756 \\
\hline Jaimes-Dueñez et al. 2017 [78] & 2015 & Meta & 1 & 0 & 242 \\
\hline Hernández et al. 2016 [5] & 2013 & $\begin{array}{l}\text { Meta, Guajira, Cesar, Antioquia, Norte } \\
\text { de Santander, Casanare, Huila }\end{array}$ & 7 & 245 & 0 \\
\hline Travi et al. 1994 [98] & 1991 & Nariño, Córdoba & 2 & 0 & 394 \\
\hline Sandoval et al. 2010 [70] & 2004-2006 & Norte de Santander & 1 & 123 & 0 \\
\hline Reyes et al. 2017 [15] & 2014 & Santander & 1 & 17 & 1 \\
\hline Castro-Salas et al. 2013 [64] & 2010 & Vichada & 1 & 28 & 0 \\
\hline
\end{tabular}

Notes: Letters (a) and (b) refer to different studies by the same first author in a single year. The study by León et al. [33] was included as part of the qualitative analyses (Tables 2 and 3 ) but not as part of the meta-analyses as this is a study on parasite isolates only

Abbreviations: mun, municipalities; SNSM, Sierra Nevada de Santa Marta; L, localities; V, villages

Two orders, Artiodactyla and Lagomorpha, were excluded from the quantitative analyses due to small sample size. Within the order Artiodactyla (i.e. white-tailed deer, collared peccary and boar), a prevalence ranging between $0-5 \%$ was registered. For the order Lagomorpha, only one study was found for the European rabbit Oryctolagus cuniculus with a prevalence of $22 \%(2 / 9)$. 


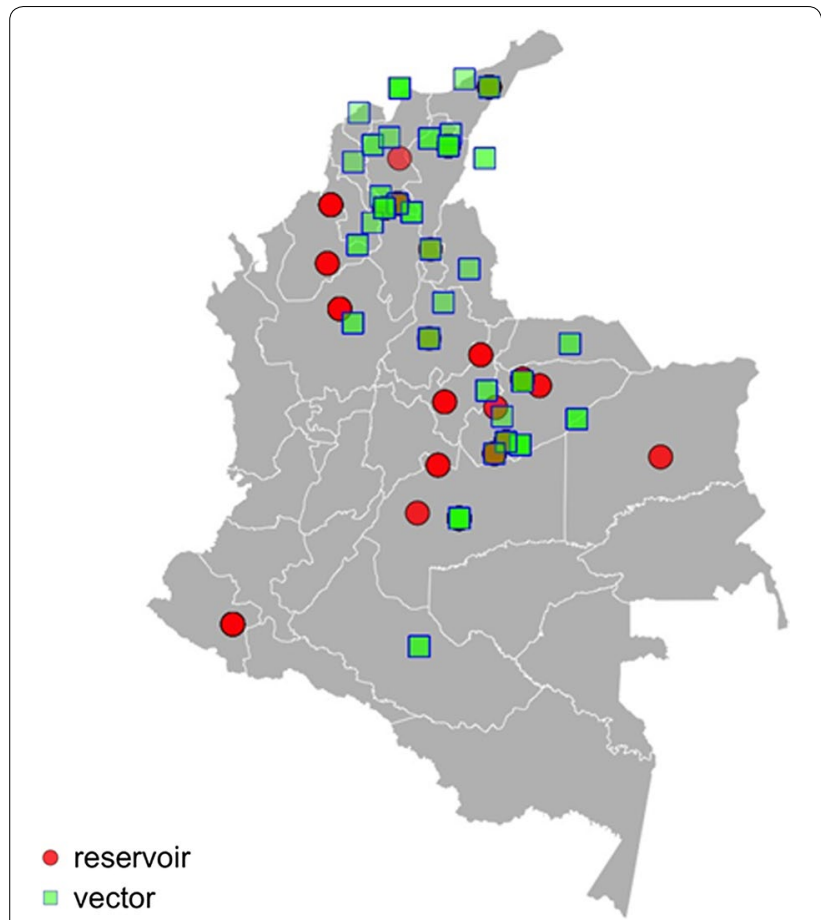

Fig. 2 Map showing the geographical distribution of the samples used in individual studies for both animal reservoirs (red circles) and triatomine vectors (green pictures) investigated for T. cruzi infection in Colombia

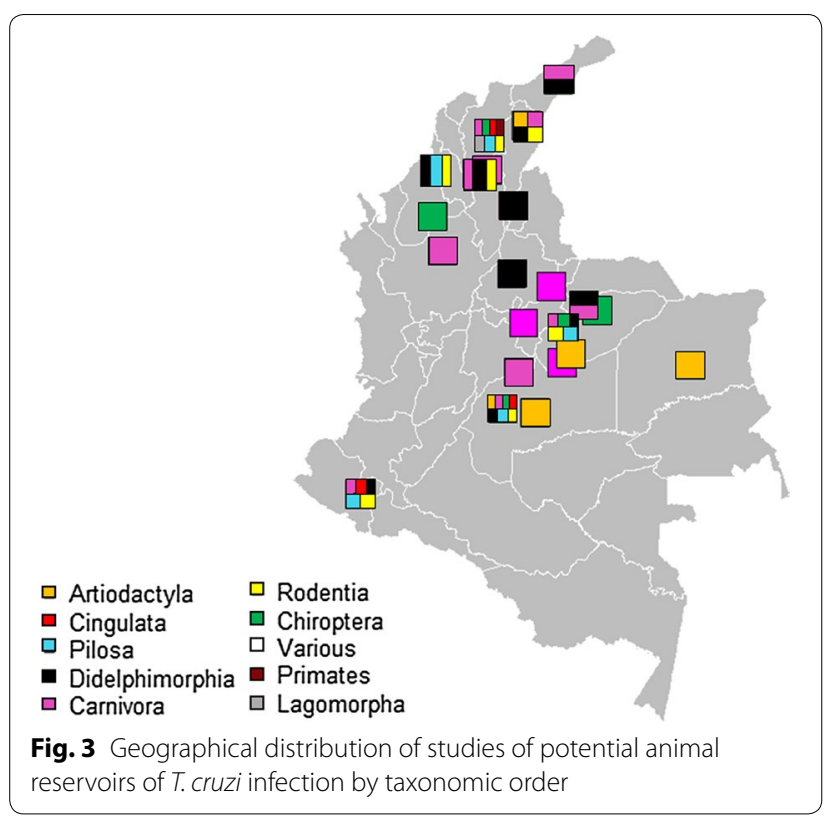

The two orders with the highest number of studies were Didelphimorphia and Carnivora, with 11 studies each. The results are presented in Fig. 6. Not all of these studies were included in meta-analyses due to sample size restrictions. Eleven studies reported Didelphimorphia. However, only five of them were included for pooled estimates due to sample size restrictions. The estimated prevalence for common opossum (Didelphis marsupialis) was $48.0 \%$ (95\% CI: $26-71 \% ; I^{2}=88 \%, \tau^{2}=0.07, P<0.01$ ). The order Carnivora was the only one with reports for prevalence based on serological tests. The most relevant species, the domestic dog (Canis lupus familiaris), presented a high pooled prevalence of $T$. cruzi infection measured by serological tests $(24.0 \%, 95 \%$ CI: $1-64 \%$; $\left.I^{2}=98 \%, \tau^{2}=0.17, P<0.01\right)$. Only one study included the kinkajou (Potos flavus) and presented a point prevalence of T. cruzi of $44.4 \%$. The order Chiroptera (bats) and the order Rodentia (rodents) were found with a pooled prevalence of $15.0 \%$ (95\% CI: $5-29 \% ; I^{2}=96 \%, \tau^{2}=0.04$, $P<0.01)$ and $6.0 \%$ (95\% CI: $2-12 \%, I^{2}=77 \%, \tau^{2}=0.01$, $P<0.01)$, respectively.

\section{Pooled prevalence of T. cruzi infection in triatomines}

Among the 18 triatomine species studied, the highest pooled prevalence for T. cruzi infection was found for T. maculata $68.0 \%$ (95\% CI: $62-74 \% ; I^{2}=0.0 \%, \tau^{2}=0.0$, $P<0.0001)$, followed by sylvatic $R$. prolixus $62.0 \%(95 \%$ CI: $\left.38-84 \% ; I^{2}=95 \%, \tau^{2}=0.05, P<0.01\right)$ and sylvatic $R$. pallescens $54.0 \%$ (95\% CI: $31-71 \% ; I^{2}=86 \%, \tau^{2}=0.03$, $P<0.01)$. Another species of great public health importance, $T$. dimidiata, presented a pooled prevalence of 20.0\% (95\% CI: 8-35\%; $I^{2}=90 \%, \tau^{2}=0.02, P<0.01$ ).

For the most studied species ( $R$. prolixus), 13 studies were found with disaggregated data by ecotope of capture. Although heterogeneity was found similar in both sylvatic and domestic ecotopes $\left(I^{2}=97 \%, \tau^{2}=0.15\right.$, $P<0.01$ and $I^{2}=95 \%, \tau^{2}=0.05, P<0.01$, respectively), the highest prevalence was obtained for the sylvatic cycle (62.0\%, 95\% CI: 38-84\%; $I^{2}=95 \%, \tau^{2}=0.05, P<0.01$ ). Figure 7 shows the meta-analysis for $R$. prolixus by ecotope of collection. Details of all disaggregated results by diagnostic method are presented in Table 5 and further details in Additional file 2: Table S6.

\section{Publication bias and sensitivity analysis}

Egger's test was used for cases with at least five studies included for either reservoirs or triatomines. Only one animal reservoir family (Canidae) was found with evidence of potential publication bias. After applying the Trimfill method, estimated prevalence changed from $14.0 \%$ (95\% CI: $1-37 \%$ ) to $32.0 \%$ (95\% CI: $10-58 \%$ ). Publication bias results are presented in Additional file 2: Table S7 and Figures S2-S4.

On the other hand, sensitivity analysis by repeating all pooled estimates omitting one study at a time did not 
Table 2 Taxonomic classification of potential animal reservoir and evidence of infection with T. cruzi in Colombia

\begin{tabular}{|c|c|c|c|c|}
\hline Family & Genus & Species & Common name (as used in Colombia) & T. cruzi infection \\
\hline \multicolumn{5}{|l|}{ Order Artiodactyla } \\
\hline \multirow[t]{2}{*}{ Cervidae } & Mazama & M. gouazoubira medemi & Viracho & Yes \\
\hline & Odocoileus & O. virginianus & Venado de cola blanca & Yes \\
\hline Suidae & Sus & S. scrofa & Jabalí & No \\
\hline Tayassuidae & Tayassu & T. albirostris & Pecarí barbiblanco o baquira & No \\
\hline \multicolumn{5}{|l|}{ Order Carnivora } \\
\hline \multirow[t]{2}{*}{ Canidae } & Canis & C.lupus & Perro & Yes \\
\hline & Cerdocyon & C. thous & Zorro cangrejero & No \\
\hline \multirow[t]{3}{*}{ Felidae } & Felis & F. concolor & Puma & No \\
\hline & & F.pardalis & Ocelote & No \\
\hline & & F. silvestris catus & Gato doméstico & Yes \\
\hline Procyonidae & Potos & P. flavus & Perro de monte & Yes \\
\hline \multicolumn{5}{|l|}{ Order Chiroptera } \\
\hline \multirow[t]{10}{*}{ Phyllostomidae } & Artibeus & A. fuliginosus & Murciélago frugívoro neotropical & Yes \\
\hline & & A. jamaicensis & Murciélago frugívoro de Jamaica & Yes \\
\hline & & A. lituratus & Murciélago frugívoro neotropical & Yes \\
\hline & & A. planirostris & Murciélago frugívoro neotropical & Yes \\
\hline & & A. phaeotis & Murciélago frugívoro neotropical & Yes \\
\hline & Carollia & C. perspicillata & Murciélago común frugívoro & Yes \\
\hline & Desmodus & D. rotundus & Vampiro de Araza & Yes \\
\hline & Glossophaga & Glossophaga sp. & Murciélago neotropicales & Yes \\
\hline & Phyllostoma & P. discolour & Murciélago nariz de lanza & No \\
\hline & Sturnira & Sturnira. sp. & Murciélago microquiróptero & No \\
\hline \multirow[t]{4}{*}{ Vespertilionidae } & Eptesicus & E. furinalis & Murciélago pardo común & Yes \\
\hline & Lasiurus & L. borealis & Murciélago Colorado & No \\
\hline & Myotis & M. nigricans & Murciélago negro pequeño & No \\
\hline & Myotis & M. oxyotus & Murciélago negro pequeño & Yes \\
\hline \multirow[t]{4}{*}{ Molossidae } & Eumops & E.perotis & Murciélago gigante de bonete & No \\
\hline & Molossus & M. bondae & Murciélago mastín de Bonda & Yes \\
\hline & & M. major & Murciélago de cola libre insectívoro & No \\
\hline & & M. molossus & Murciélago mastín común & No \\
\hline \multirow[t]{2}{*}{ Noctilionidae } & Noctilio & N. labialis & Murciélago Pescadores & No \\
\hline & & N. leporinus & Murciélago pescador & No \\
\hline Emballonuridae & Rhynchonycteris & R. naso & Murciélago narigón & Yes \\
\hline \multicolumn{5}{|l|}{ Order Cingulata } \\
\hline \multirow[t]{4}{*}{ Dasypodidae } & Dasypus & D. kappleri & Armadillo & Yes \\
\hline & & D. novemcinctus & Armadillo de 9 bandas & Yes \\
\hline & & D. sabanicola & Cachicamo Sabanero & Yes \\
\hline & Proechymis & P. giganteus & Armadillo gigante & No \\
\hline \multicolumn{5}{|c|}{ Order Lagomorpha } \\
\hline Leporidae & Oryctolagus & O. cuniculus & Conejo & Yes \\
\hline \multicolumn{5}{|c|}{ Order Didelphimorphia } \\
\hline \multirow[t]{7}{*}{ Didelphidae } & Didelphis & D. marsupialis & Zarigueya común & Yes \\
\hline & Lutrolina & L. crassicaudata & Zarigueya de cola gruesa & No \\
\hline & Marmosa & M. andersoni & Otras zarigüeyas & No \\
\hline & & M. cf. robinsoni & Marmosa de Robinson & Yes \\
\hline & & M. murina & Zarigueya ratón & No \\
\hline & Metachirus & M. nudicaudatus & Comadreja de anteojos & Yes \\
\hline & Monodelphis & Monodelphis sp. & Zarigueyas de pequeños tamaños & No \\
\hline
\end{tabular}


Table 2 (continued)

\begin{tabular}{|c|c|c|c|c|}
\hline Family & Genus & Species & Common name (as used in Colombia) & T. cruzi infection \\
\hline & Philander & P.opossum & Zarigueya gris de cuatro ojos & No \\
\hline & Caluromys & C. lanatus & Zarigüeya lanuda oocidental & Yes \\
\hline \multicolumn{5}{|l|}{ Order Pilosa } \\
\hline Bradypodidae & Bradypus & B. variegatus & Perezoso bayo & No \\
\hline Megalonychidae & Choloepus & C. hoffmanni & Perezoso de dos dedos de Hoffmann & No \\
\hline Cyclopedidae & Cyclopes & C. didactylus & Oso hormiguero pigmeo & No \\
\hline \multirow{3}{*}{ Myrmecophagidae } & Myrmecophaga & M. tridactyla & Oso hormiguero gigante & Yes \\
\hline & Tamandua & T. tetradactyla & Oso hormiguero de chaleco & Yes \\
\hline & & T.mexicana & Oso hormiguero & Yes \\
\hline \multicolumn{5}{|l|}{ Order Primates } \\
\hline Atelidae & Alouatta & A. caraya & Primates & No \\
\hline \multicolumn{5}{|l|}{ Order Rodentia } \\
\hline Caviidae & Cavia & C.porcellus & Cuy & No \\
\hline Erethizontidae & Coendou & Coendou sp. & Puercoespin americano de cola larga & No \\
\hline Cuniculidae & Cuniculus & C.paca & Paca común, lapa & Yes \\
\hline \multirow[t]{2}{*}{ Dasyroctidae } & Dasyprocta & D. fuliginosa & Neque o picure & Yes \\
\hline & & D. punctata & Neque o guatín & No \\
\hline Heteromyidae & Heteromys & H. anomalus & Ratón mochilero & Yes \\
\hline Echimyidae & Hoplomys & H. gimnurus & Rata acorazada & No \\
\hline Caviidae & Hydrochoerus & H. hydrochaeris & Chiguiro o Capibara & Yes \\
\hline Muridae & Mus & M. musculus & Ratón casero & No \\
\hline \multirow[t]{9}{*}{ Cricetidae } & Neacomys & N. spinosus & Roedor miomorfo & No \\
\hline & Nectomys & N. squamipes & Rata de agua brasileña & No \\
\hline & Zygodontomys & Z. brevicauda & Ratones de las cañas, pichunas & No \\
\hline & & Z.brunneus & Ratones de las cañas, pichunas & Yes \\
\hline & Sigmodon & S. alstoni & Rata de algodón & No \\
\hline & Tylomys & T. mirae & Rata trepadora Mira & Yes \\
\hline & Oryzomys & O. concolor & Ratones de arrozal & Yes \\
\hline & & O. delicates & Ratones de arrozal & No \\
\hline & & O. fulvescens & Ratones de arrozal & No \\
\hline \multirow[t]{3}{*}{ Echimyidae } & Proechymis & P. semiespinosus & Ratas espinosas, ratones de monte & Yes \\
\hline & & P. oconnelli & Guira, ratas espinosas, ratones de arrozal & No \\
\hline & Diplomys & Diplomys sp. & Rata Espinosa & Yes \\
\hline \multirow[t]{2}{*}{ Muridae } & Rattus & R. rattus & Rata negra o rata común & Yes \\
\hline & & R. norvegicus & Rata gris o rata de alcantarilla & No \\
\hline
\end{tabular}

show a significant change in the estimated pooled prevalence, see Additional file 2: Figures S5, S6 for details.

\section{Quality assessment}

Among the 39 studies included in the meta-analysis, $67 \%$ were classified as high-quality, $21 \%$ as moderatequality and $12 \%$ as low-quality. The main problems found in the low-quality studies included unclear information on the study period, lack of details on taxonomic classification, and not enough information on selection methods of the subjects. The details are presented in Additional file 2: Tables S8, S9 and Figure S7.

\section{Discussion}

This systematic review obtained 39 studies that included 71 species of potential reservoirs and 18 species of triatomine insects investigated for the presence of $T$. cruzi infection in Colombia. Among them, we found solid evidence of infection in 38 reservoirs and 14 triatomine vector species. To the best of our knowledge, this is the first study that systematically identified this evidence and analysed the heterogeneity of infection rates of $T$. cruzi 


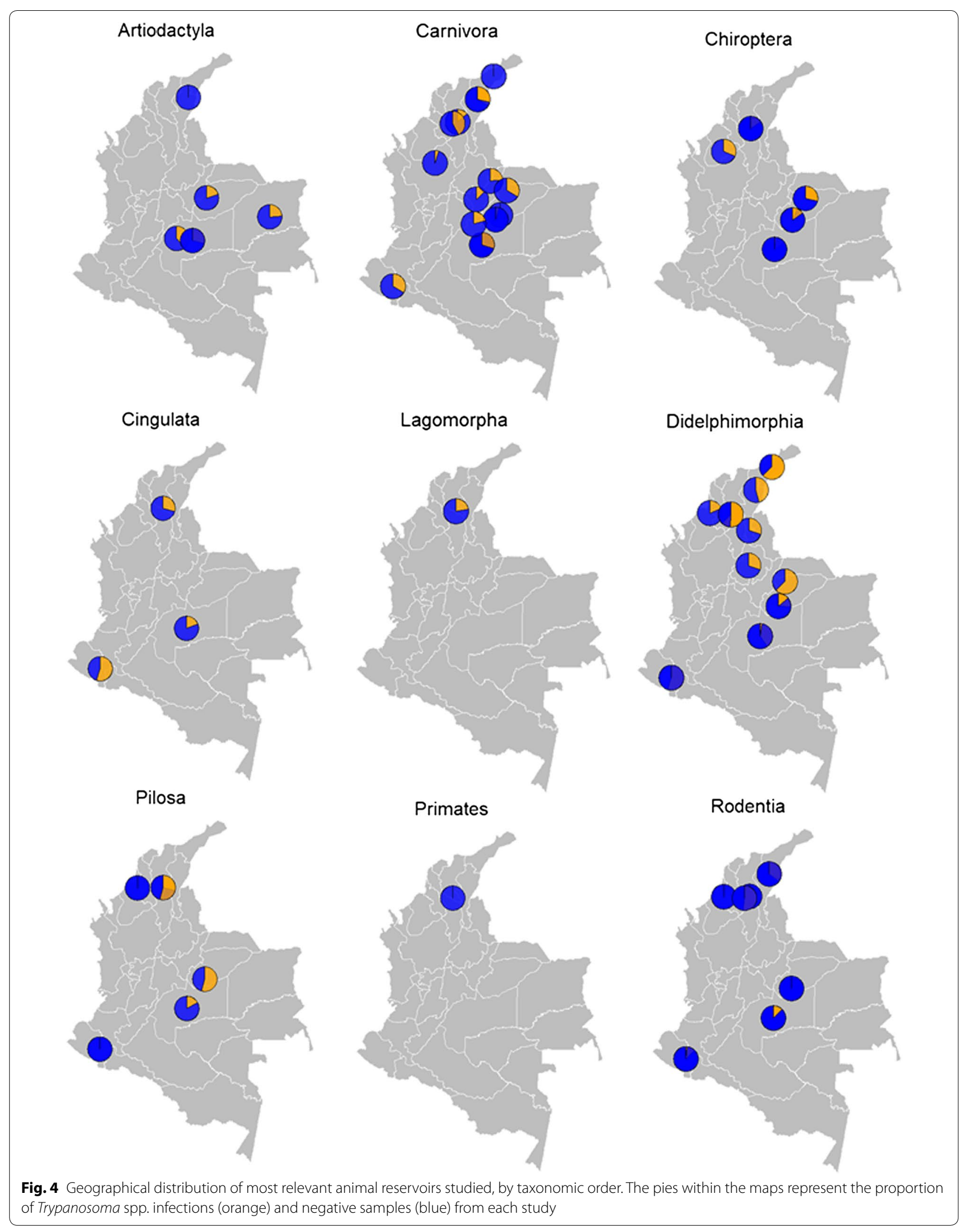


Table 3 Evidence of triatomine species studied for T. cruzi infection in Colombia

\begin{tabular}{|c|c|c|c|}
\hline Genus & Species & $\begin{array}{l}\text { Evidence of T. cruzi } \\
\text { infection }\end{array}$ & Geographical distribution \\
\hline \multirow[t]{2}{*}{ Belminus } & B. ferroae & No & Norte de Santander \\
\hline & B. herreri & Yes & Cesar \\
\hline \multirow[t]{2}{*}{ Eratyrus } & E. mucronatus & No & Boyaca \\
\hline & E. cuspidatus & Yes & Atlantico, Bolivar, Magdalena \\
\hline Cavernicola & C. pilosa & Yes & Meta \\
\hline Psammolestes & P. arthuri & No & Casanare, Meta \\
\hline \multirow[t]{3}{*}{ Panstrongylus } & P. lignarius & $\mathrm{No}^{\mathrm{a}}$ & Meta \\
\hline & P.geniculatus & Yes & Atlantico, Boyaca, Casanare, Magdalena, Meta, Santander, SNSM, Sucre, Vichada \\
\hline & P. rufotuberculatus & Yes & Antioquia, Boyaca, SNSM \\
\hline \multirow[t]{5}{*}{ Rhodnius } & R. pallescens & Yes & Bolivar, Boyaca, Cesar, Magdalena, Santander, SNSM \\
\hline & R.prolixus & Yes & Boyaca, Caqueta, Casanare, Cordoba, Guajira, Meta, SNSM, Vichada \\
\hline & R.pictipes & Yes & Boyaca, Caqueta, SNSM \\
\hline & R. robustus & $Y_{e s}^{b}$ & \\
\hline & R. colombiensis & Yes $^{\mathrm{b}}$ & \\
\hline \multirow[t]{4}{*}{ Triatoma } & T. dimidiata & Yes & Boyaca, Cordoba, Guajira, SNSM \\
\hline & T. maculata & Yes & Bolivar, Boyaca, Casanare, Guajira, Magdalena, Meta, SNSM, Vichada \\
\hline & T. venosa & Yes & Boyaca \\
\hline & T. dispar & $Y_{e s}^{b}$ & \\
\hline
\end{tabular}

a There is evidence of infection with Trypanosoma spp., but not confirmed evidence of $T$. cruzi due to the diagnostic method used (microscopic examination of extruded faeces)

b Obtained from studies on isolates of T. cruzi parasites

Abbreviations: SNSM, Sierra Nevada de Santa Marta

infection in both animal (non-human) reservoirs and triatomine insects in Colombia.

\section{Evidence of $T$. cruzi infection in animals in Colombia}

Among the 38-mammal species identified as T. cruzi reservoirs, 29 belong to four orders exhibiting the highest prevalence: Didelphimorphia (35.0\%); Carnivora (17.0\%); Rodentia (6.0\%); and Chiroptera (15.0\%). A subgroup analysis was only possible for Carnivora and Didelphimorphia.

Within the order Didelphimorphia, D. marsupialis (common opossum) presented the highest pooled prevalence, $48.0 \%$. The epidemiological importance of this mammal is highlighted for several reasons including its high susceptibility to infection, ability to act as both reservoir and vector, its persistent high infection rates and its highly adaptive behaviour that allows it to live close to both domestic and sylvatic habitats and to transport infection between households [17, 34]. Opossums are mammals with night habits and a clear ability to adapt to artificial ecosystems. In both rural and urban areas, these animals frequently visit houses in search for food, establishing close contact with humans [14, 17, 35]. These animals have been implicated in outbreaks resulting from oral transmission in different areas including in Colombia, suggesting they are able to contaminate human food sources via anal secretions [36-38]. The high pooled prevalence found for this species in our study and the already documented tolerance to TcI infection (the same DTU identified in human cases from oral transmission) confirms opossum as the most important species so far identified for transmission to humans in the sylvatic cycle of T. cruzi $[4,39,40]$.

Our results for the order Carnivora show that Canis lupus familiaris presented the highest pooled prevalence $(17.0 \%)$ in the domestic habitat, with a non-significant difference between serological (24.0\%; 95\% CI: 1-64\%) and non-serologicalal tests (14.0\%; 95\% CI: $1-31 \%)$. Interestingly, diverging results have been found in other countries using parasitological methods [18]. Whereas in the Argentinian Chaco, Canis lupus familiaris has been reported as the most important animal in the domestic cycle of $T$. cruzi, with both a high prevalence and a high parasitemia [41, 42], other studies in Brazil have found the domestic dog only with a high seroprevalence, but with a low parasitaemia [43]. It has been suggested that domestic dogs have a paramount role for linking sylvatic and domestic cycles and suggesting that this family could be used as an indicator of recent local transmission [39]. Another interesting contrast occurs with regards to the family Felidae. Species of this family have been reported infected in studies from Argentina and Brazil [44, 45], 


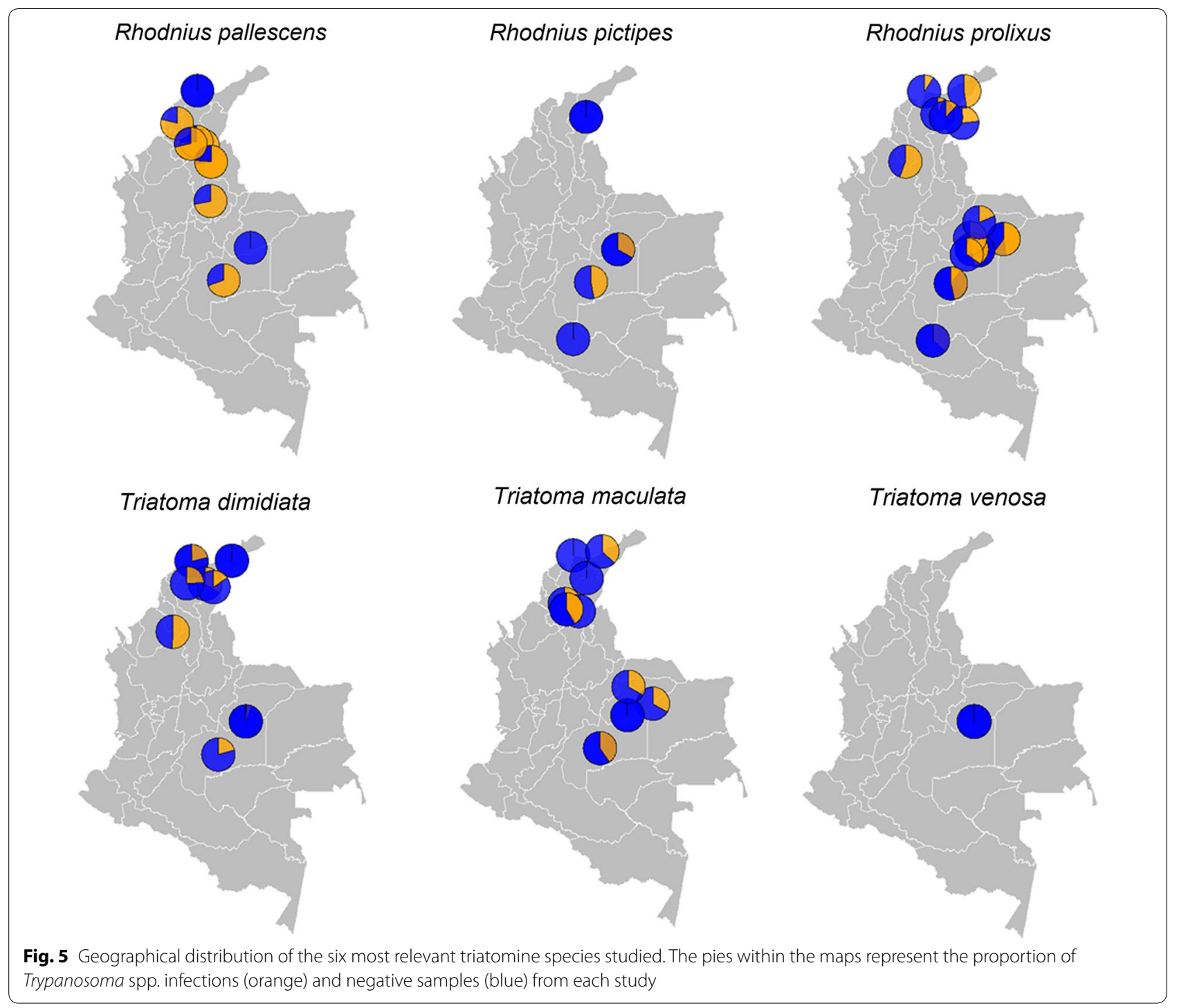

whereas in our systematic review in Colombia only one study for this family was identified, which reported no $T$. cruzi infection [46].

Another important finding from our review is the estimated pooled prevalence for the orders Chiroptera and Rodentia, $15.0 \%$ (95\% CI: 5-29\%) and 6.0\% (95\% CI: $2-12 \%$ ), respectively. The order Chiroptera (to which different species of bats belong) has been reported commonly sharing habitats with triatomines. Their ability to travel long distances and their long lifespan that ranges between 15-50 years [47] make them a very important taxonomic order to keep T. cruzi transmission active [48, 49]. Within the Chiroptera, the frugivorous Neotropical bats were the most commonly studied and reported with infected species $[50,51]$. Interestingly, it has been documented that T. cruzi infection in bats could occur via different routes that include oral and congenital transmission, the latter of which could explain the high T. cruzi prevalence even in non-insectivorous bats [18].

An additional discrete typing unit identified in bats, TcBat, has been found genetically related to TcI [4]. In recent years, TcBat was isolated from a human case, a five-year-old girl in Colombia [52]. The authors of this case study suggest vectorial or oral as potential infection sources [52]. The high prevalence of $T$. cruzi infection in the order Chiroptera found in our study confirms that species of this order are very relevant reservoirs in sylvatic T. cruzi transmission. Additionally, TcBat detected in humans also reveals the potential relevance of Chiroptera to T. cruzi human infection. TcBat is not usually investigated via molecular diagnostic methods so that the real magnitude of human infection by TcBat still remains unknown [4,52]. 
Table 4 Results of point or pooled prevalence estimates (meta-analysis using random effects model) by serological vs non-serological methods for the different orders of potential Trypanosoma cruzi animal reservoirs studied in Colombia

\begin{tabular}{|c|c|c|c|c|c|c|c|c|c|}
\hline Order/family/species & Diagnostic subgroup & No. of studies & $\begin{array}{l}\text { Potential } \\
\text { reservoirs } \\
(n)\end{array}$ & $\begin{array}{l}\text { Potential } \\
\text { reservoirs } \\
(+)\end{array}$ & $\begin{array}{l}\text { Pooled } \\
\text { prevalence } \\
\text { (\%) }\end{array}$ & $95 \% \mathrm{Cl}$ & $P^{2}(\%)$ & $T^{2}$ & $P$-value \\
\hline Carnivora & Non-serological & 11 & 940 & 347 & 17 & $5-33$ & 96 & 0.08 & $<0.01$ \\
\hline \multirow[t]{3}{*}{ Family Canidae/Canis lupus familiaris } & Serological & 4 & 430 & 196 & 24 & $1-64$ & 98 & 0.17 & $<0.01$ \\
\hline & Non-serological & 5 & 257 & 89 & 14 & $1-37$ & 93 & 0.07 & $<0.01$ \\
\hline & Mixed & 1 & 242 & 62 & 26 & $2-31$ & - & - & - \\
\hline Family Felidae & Non-serological & 1 & 11 & 0 & 0 & $0-15$ & - & - & - \\
\hline Chiroptera & Non-serological & 6 & 20,267 & 1010 & 15 & $5-29$ & 96 & 0.04 & $<0.01$ \\
\hline Cingulata & Non-serological & 1 & 21 & 4 & 19 & $5-39$ & - & - & - \\
\hline Pilosa & Non-serological & 1 & 46 & 0 & 0 & $0-4$ & - & - & - \\
\hline Didelphimorphia & Non-serological & 5 & 310 & 80 & 35 & $16-57$ & 92 & 0.06 & $<0.01$ \\
\hline Didelphis marsupialis & Non-serological & 5 & 161 & 73 & 48 & $26-71$ & 88 & 0.07 & $<0.01$ \\
\hline Other Didelphis & Non-serological & 3 & 148 & 6 & 3 & $0-10$ & 62 & 0.09 & 0.07 \\
\hline Primates & Non-serological & 1 & 343 & 53 & 15 & $12-19$ & - & - & - \\
\hline Rodentia & Non-serological & 5 & 799 & 59 & 6 & $2-12$ & 77 & 0.01 & $<0.01$ \\
\hline Other non-classified species & Non-serological & 1 & 10 & 2 & 20 & $1-51$ & - & - & - \\
\hline
\end{tabular}

Notes: Non-serological: includes parasitological methods (blood smears hemoculture and xenodiagnostic) and molecular methods (PCR)

Serological: includes ELISA, IFAT or rapid tests based on the whole parasite or recombined antigens; +: positive

Determining the importance of animal reservoirs in the transmission of T. cruzi depends on several factors, such as their ability to be infectious in natural conditions and the concentration of parasites in the blood (parasitemia), which in turn is determined by the species of the animal reservoir, the genotype of $T$. cruzi, the nutritional status of the reservoir, the route of infection and the concomitant infection that ensures its diffusion and maintenance in nature [34]. With regard to rodents, the importance of these animals as $T$. cruzi reservoirs includes their ability to maintain the parasite for long periods of time [53]. Additionally, it has been suggested that rodents act as secondary reservoirs in both domestic and sylvatic habitats where they can play a role in the oral transmission route as part of the food chain to larger predators $[18,54$, 55].

\section{Evidence of $T$. cruzi infection in triatomine insects in Colombia}

In Colombia, the triatomine species most efficiently adapted to human habitats are $R$. prolixus, $T$. dimidiata and T. venosa [56]. In our study, the pooled prevalence of infection with these species was $46.0 \%$ (95\% CI: 23-69\%), $20.0 \%$ (95\% CI: $8-35 \%$ ) and $0.004 \%$ (95\% CI: $0-1 \%$ ), respectively.

Rhodnius prolixus was the species with the highest number of studies, which allowed us to perform subgroup analysis which evidenced an important difference between sylvatic and domestic cycles, 62.0\% (95\% CI: $38-84 \%$ ) and 39.0\% (95\% CI: 4-82\%), respectively. While this triatomine species is the most important domiciliated species reported in Venezuela, Colombian and Central America, our results also highlight the importance of sylvatic colonies. Due to the highly anthropophilic behaviour of this species, its ability to become domiciliated and its high transmission efficiency [57], our results add evidence of the relevance of this species in Colombia, both in domestic and sylvatic cycles. Interestingly, the sylvatic presence of $R$. prolixus has been reported increasingly in both the native palm trees (Attalea butyracea) and introduced agro-industrial palms (Elaeis guineensis) across the plains of Colombia [51, 58, 59].

The triatomine species with the highest prevalence found in our study was T. maculata but only located in the northeast part of the country $[60,61]$. In the past, due to its ornithophilic behaviour, it was traditionally considered not very relevant for human transmission [62]. However, recent studies demonstrate their potential importance due to their high prevalence rates and colonisation index [5, 60, 61, 63-65].

Another triatomine species with a very high prevalence was $R$. pallescens with geographical predominance in the north-west part of the country (Caribbean region). This vector has been also associated with Attalea butyracea palms [63, 66-87], has been reported frequently in Costa Rica and Nicaragua [67] and it is considered the main vector in Panama $[68,69]$. Importantly, this species has been found commonly circulating in areas of oral outbreaks in Colombia [37]. 


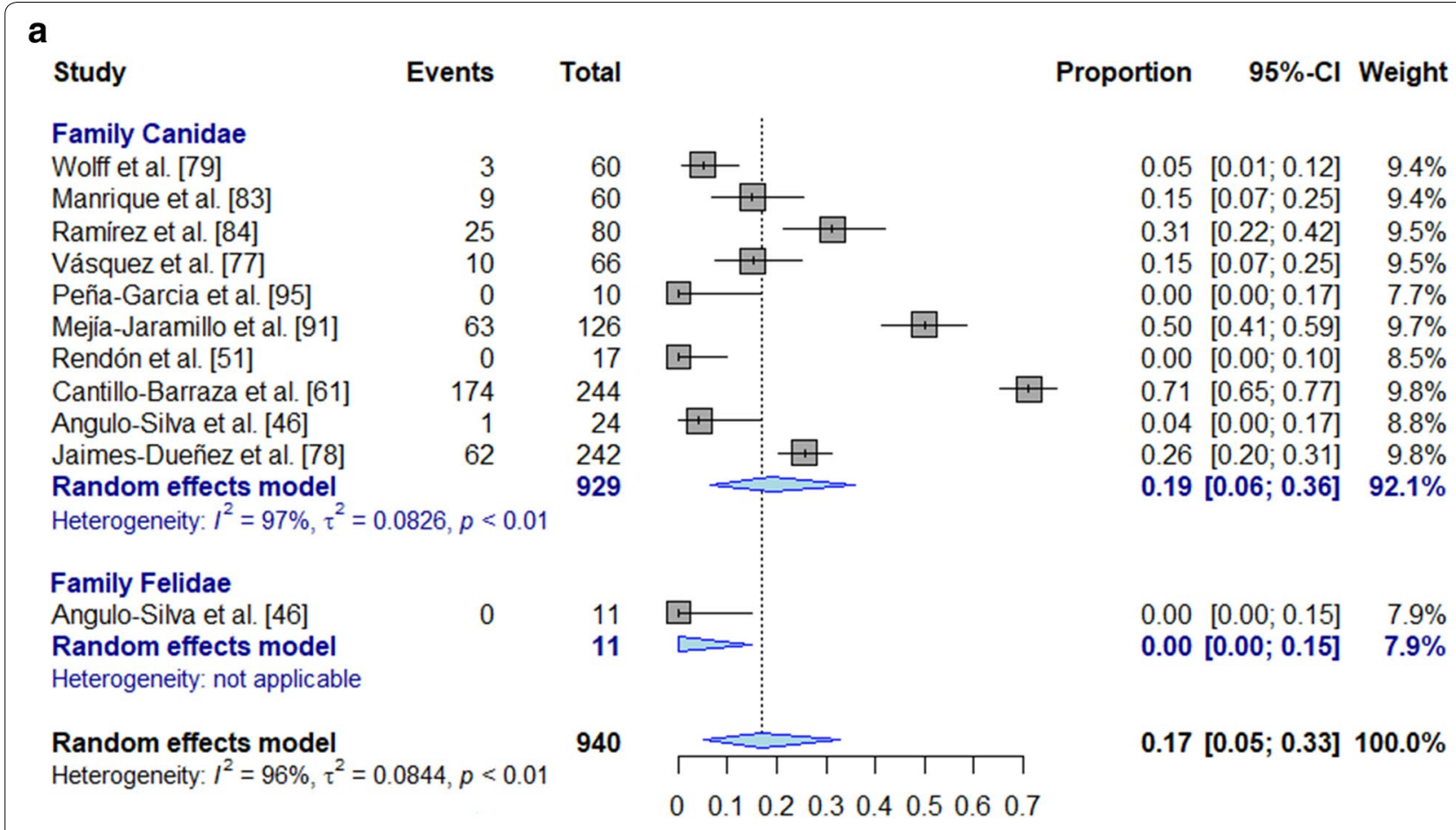

b

Study Events Total

Subgroup Didelphis marsupialis

D' Alessandro et al. [71] $\quad 25 \quad 62$

Travi et al (1). [98] $13 \quad 18$

Travi et al (2). [98] $\quad 3 \quad 22$

Cantillo-Barraza et al. [66] $\quad 19 \quad 22$

Rendón et al. [51]

Cantillo-Barraza et al. [61]

$5 \quad 24$

Random effects model

813

Heterogeneity: $I^{2}=88 \%, \tau^{2}=0.0696, p<0.01$

161

Subgroup other Didelphis

D' Alessandro et al. [71]

Travi et al (1). [98]

Rendón et al. [51]

Random effects model

Heterogeneity: $I^{2}=62 \%, \tau^{2}=0.0091, p=0.07$

Random effects model

Heterogeneity: $I^{2}=94 \%, \tau^{2}=0.1204, p<0.01$

309

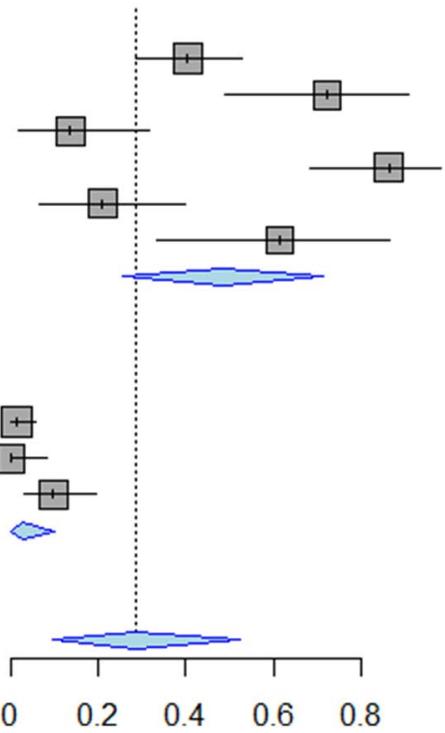

Proportion $\quad 95 \%-\mathrm{Cl}$ Weight

$\begin{array}{lll}0.40[0.28 ; 0.53] & 11.6 \% \\ 0.72[0.49 ; 0.91] & 10.8 \% \\ 0.14[0.02 ; 0.32] & 11.0 \% \\ 0.86[0.68 ; 0.98] & 11.0 \% \\ 0.21[0.07 ; 0.40] & 11.1 \% \\ 0.62[0.33 ; 0.87] & 10.4 \% \\ \mathbf{0 . 4 8}[0.26 ; 0.71] & \mathbf{6 5 . 8 \%}\end{array}$

$0.01[0.00 ; 0.06] \quad 11.7 \%$

$0.00[0.00 ; 0.08] \quad 10.9 \%$

$0.10[0.03 ; 0.19] \quad 11.5 \%$

$0.03[0.00 ; 0.10] \quad 34.2 \%$

$0.29[0.10 ; 0.52] 100.0 \%$

Fig. 6 Meta-analysis for pooled prevalence of T. cruzi infection using random effects model for the orders Carnivora (a) and Didelphimorphia (b) without disaggregation by diagnostic tests used. Numbers 1 and 2 in parentheses indicate the same study but a different geographical distribution

Our study did not find evidence of T. cruzi infection in four species (Belminus ferroae, Eratyrus mucronatus, Psammolestes arthuri and Panstrongylus lignarius) out of the 18 studied here. Belminus ferroae has been considered as not a very relevant vector for human transmission due to its limited hematophagous behaviour [70]. Eratyrus mucronatus has been reported in two studies, but it remains unclear whether or not they were found with natural infection $[46,58]$. Psammolestes arthuri has been reported in two studies associated to nests of birds but with no natural infection $[65,71]$. Finally, P. lignarius has been reported as 


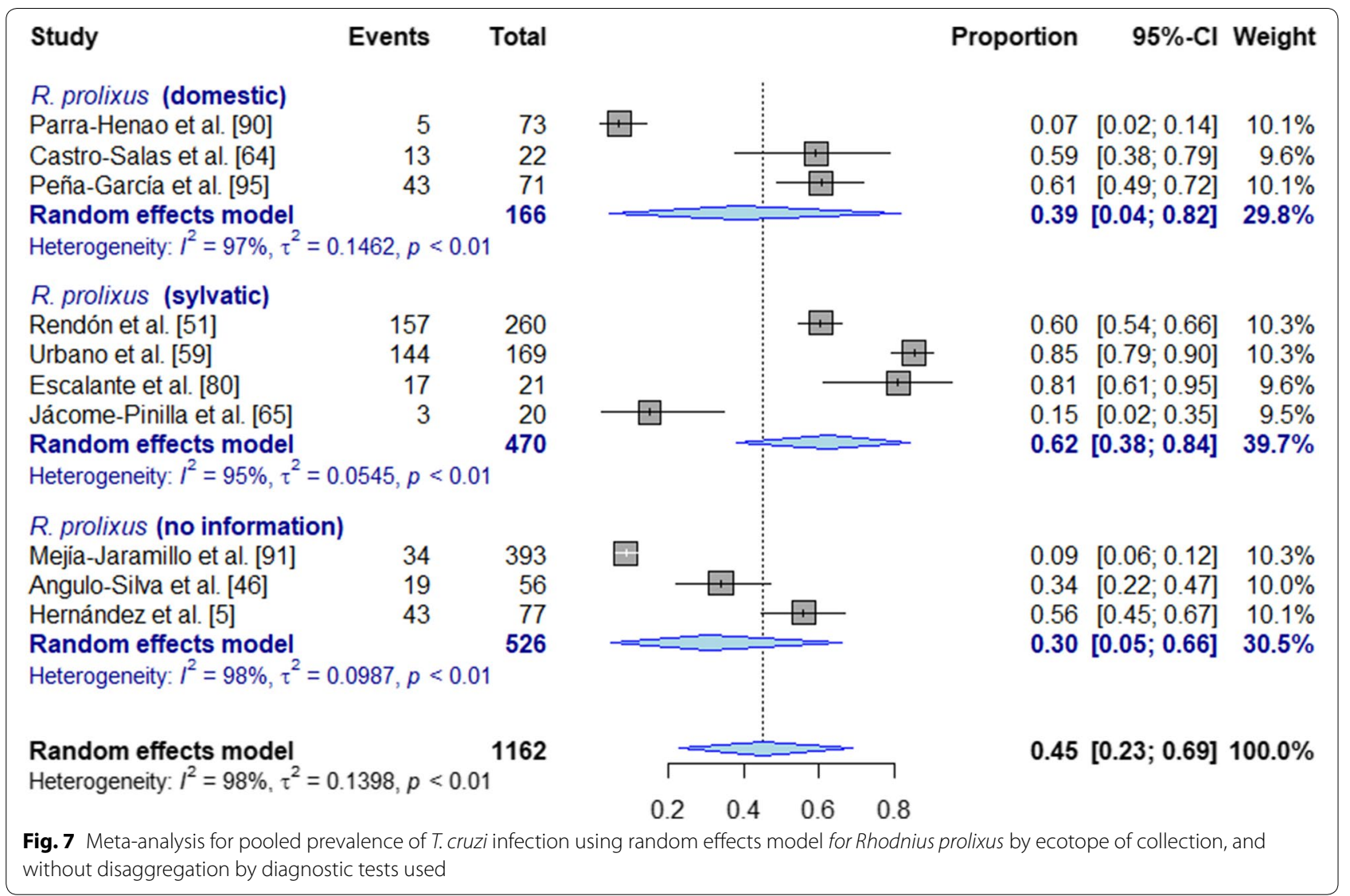

infected by Trypanosoma spp. based on non-speciesspecific diagnostic method (microscopy) [71].

Finally, other triatomine species that include $\mathrm{R}$. robustus, R. colombiensis and T. dispar and the animal species Caluromys lanatus have been found infected with T. cruzi in Colombia and are reported in a study of parasite isolates [33]. However, as that study does not correspond to a prevalence assessment, it was not possible to use those results for the quantitative analyses.

\section{Public health implications of these results}

Several types of dynamic models for Chagas disease have been developed [72]. Most of them have been restricted to domiciliated habitats and in some cases included sylvatic cycle with a single vector and single host. The results from our study show that the heterogeneity of species involved in the sylvatic cycle and the heterogeneity of infection rates among them are worth considering when modelling particularly the sylvatic cycle, as some pioneer studies have started to consider by using multihost models [73].

Several cultural aspects related to human contact with some of the animal species described in our study could be potentially relevant. Several animal species with clear evidence as T. cruzi reservoirs are considered common food sources in indigenous and rural communities. Factors associated with the hunting, sacrifice and manipulation of these animal species could represent a potential risk for accidental contamination with T. cruzi in humans. Of particular importance, several species from the order Cingulata (popularly known armadillos and cachicamos) and from the order Chiroptera (bats) are believed to have curative properties in some communities; for this reason their blood is consumed immediately after sacrifice as part of curative rituals, a practice described even from the pre-Columbian era $[74,75]$.

The results from this study have several potential public health implications. First, to our knowledge, this study is a first baseline, accounting for the diversity of reservoirs and triatomine vectors participating in $T$. cruzi 
Table 5 Results of point or pooled prevalence estimates (meta-analysis using random effects model) for triatomine species by specific and non-specific T. cruzi infection in Colombia

\begin{tabular}{|c|c|c|c|c|c|c|c|c|c|}
\hline Species & Diagnostic subgroup & No. of studies & $\begin{array}{l}\text { Triatomine } \\
\text { bugs }(n)\end{array}$ & $\begin{array}{l}\text { Triatomine } \\
\text { bugs }(+)\end{array}$ & $\begin{array}{l}\text { Pooled } \\
\text { prevalence } \\
(\%)\end{array}$ & $95 \% \mathrm{Cl}$ & $R^{2}(\%)$ & $T^{2}$ & $P$-value \\
\hline B. ferroae & T. cruzi & 1 & 123 & 0 & 0 & $0-1$ & - & & \\
\hline B. herreri & T. cruzi & 1 & 44 & 4 & 9.09 & $2-20$ & - & - & - \\
\hline C. pilosa & Trypanosoma spp. & 1 & 28 & 2 & 7.1 & $0-20$ & - & - & - \\
\hline E. cuspidatus & T. cruzi & 1 & 16 & 9 & 56.3 & $31-80$ & - & - & - \\
\hline P. arthuri & Trypanosoma spp. & 1 & 78 & 0 & 0 & $0-2$ & - & - & - \\
\hline \multirow[t]{2}{*}{ P. geniculatus } & T. cruzi & 1 & 85 & 60 & 70.6 & $6-8$ & - & - & - \\
\hline & Trypanosoma spp. & 1 & 368 & 10 & 1.7 & $0-3$ & - & - & - \\
\hline \multirow[t]{2}{*}{ P. rufotuberculatus } & T. cruzi & 1 & 86 & 4 & 4.7 & $1-10$ & - & - & - \\
\hline & Trypanosoma spp. & 1 & 74 & 1 & 1.3 & $0-6$ & - & - & - \\
\hline \multirow[t]{2}{*}{ R.pallescens } & T. cruzi & 6 & 317 & 192 & 54.0 & $37-71$ & 86 & 0.03 & $<0.01$ \\
\hline & Trypanosoma spp. & 1 & 66 & 35 & 53.0 & $41-65$ & - & - & - \\
\hline \multirow[t]{2}{*}{ R. pictipes } & T. cruzi & 1 & 10 & 0 & 0 & $0-17$ & - & - & - \\
\hline & Trypanosoma spp. & 1 & 11 & 1 & 9.1 & $0-35$ & - & - & - \\
\hline \multirow[t]{2}{*}{ R.prolixus } & T. cruzi & 10 & 1173 & 485 & 46.0 & $23-69$ & 98 & 0.14 & $<0.01$ \\
\hline & Trypanosoma spp. & 3 & 850 & 71 & 13.0 & $3-27$ & 95 & 0.04 & $<0.01$ \\
\hline \multirow[t]{2}{*}{ R. prolixus (domestic) } & T. cruzi & 3 & 166 & 61 & 39.0 & $4-82$ & 97 & 0.15 & $<0.01$ \\
\hline & Trypanosoma spp. & 3 & 440 & 44 & 19.0 & $1-51$ & 97 & 0.11 & $<0.01$ \\
\hline \multirow[t]{2}{*}{ R. prolixus (sylvatic) } & T. cruzi & 4 & 470 & 321 & 62.0 & $38-84$ & 95 & 0.05 & $<0.01$ \\
\hline & Trypanosoma spp. & 1 & 170 & 13 & 7.6 & $4-12$ & - & - & - \\
\hline R. prolixus (peridomestic) & Trypanosoma spp. & 1 & 10 & 0 & 0 & $0-17$ & - & - & - \\
\hline \multirow[t]{2}{*}{ R. prolixus (not specified) } & T. cruzi & 3 & 526 & 96 & 30.0 & $5-66$ & 98 & 0.10 & $<0.01$ \\
\hline & Trypanosoma spp. & 1 & 220 & 11 & 5.0 & $2-8$ & - & - & - \\
\hline \multirow[t]{2}{*}{ T. dimidiata } & T. cruzi & 3 & 392 & 92 & 20.0 & $8-35$ & 90 & 0.02 & $<0.01$ \\
\hline & Trypanosoma spp. & 1 & 2671 & 222 & 25.0 & $0-74$ & - & - & - \\
\hline \multirow[t]{2}{*}{ T. maculata } & T. cruzi & 4 & 213 & 145 & 68.0 & $62-74$ & 0 & 0 & $<0.0001$ \\
\hline & Trypanosoma spp. & 3 & 129 & 16 & 6.0 & $0-38$ & 94 & 0.14 & $<0.01$ \\
\hline T. venosa & Trypanosoma spp. & 1 & 1115 & 5 & 0.004 & $0-1$ & - & - & - \\
\hline \multirow[t]{2}{*}{ Other non-classified triatomines } & T. cruzi & 3 & 3287 & 336 & 27.0 & $12-46$ & 94 & 0.04 & $<0.01$ \\
\hline & Trypanosoma spp. & 1 & 40 & 0 & 0.0 & $0-4$ & - & - & - \\
\hline
\end{tabular}

Notes: T. cruzi: includes all T. cruzi-specific methods (culture, PCR and mice inoculation); T. spp.: includes non-species-specific diagnostic methods (direct observation based on microscopic examination of extruded faeces); +: positive

transmission in Colombia, which can help understanding the broader risk to which human populations are exposed to. Secondly, the evidence of T. cruzi infection in animal reservoirs from different orders with a lifespan shorter than humans could be considered as an indicator of active transmission in a specific location. Finally, understanding the cultural relations between humans and several wild species studied here could potentially help inform populations on the potential risks associated with certain cultural practices.

\section{Study limitations}

Several relevant limitations arise from this research. First, the lack of sufficient details from several original papers reduces the possibility of more disaggregated analyses for some species. Secondly, our study evidences a high heterogeneity of study designs which makes it more difficult to obtain better pooled estimates [30]. Although publication bias was only detected in one of the species, we are aware that, due to the small number of studies, the test used could be underpowered and the fact that we only found this test as significant for one of the families with the highest number of studies (Canidae) confirms this limitation [31, 32]. Another relevant limitation is that no studies were excluded based on their quality assessment, also due to the very limited number of studies. However, when this sensitivity analysis was possible, we did not find difference between using all or high-quality-only 
studies. Although we are aware of this limitation, we are also aware of the limitations in conducting studies with animals and particularly in sylvatic areas. The reduced sample size of many of the eligible studies leads to very broad confidence intervals; although this is a limitation, it is also a more reliable measure of the uncertainly in the prevalence estimates from such heterogeneous types of studies.

Finally, an important limitation is related to diagnostic methods. An important recent study in triatomine vectors has identified that optical microscopy used for routine surveillance missed $\sim 50-75 \%$ of infections and wrongly scored as infected $\sim 7 \%$ of the bugs when only one slide per vector was used [75]. For animals, we found the use of various tests with high specificity for T. cruzi detection such as xenodiagnostic, haemoculture and coloured smears, and in the case of the family Canidae serological methods were used and in some cases with PCR confirmation [76, 77]. For vectors, however, most of the studies were conducted by direct microscopic observation which, as discussed above, is not highly speciesspecific. In the more recent studies PCR has also been included which certainly improves the quality of the measurement. We acknowledge that the use of optic microscopy can lead primarily to an underestimate of the prevalence infection rates in vectors. However, due the lack of data on the operative performance (sensitivity and specificity) of some of the techniques used in the original studies which can vary between years and operators, unfortunately we could not adjust the prevalence estimates in our meta-analysis. We have conducted subgroup analysis by diagnostic techniques in order to address this issue in vectors (see Table 5). This analysis suggests that techniques such as PCR (that can also differentiate species) are significantly more sensitive and able to detect highest values of the prevalence.

\section{Conclusions}

To our knowledge, this is the first systematic evaluation and quantitative analysis of $T$. cruzi infection rates in triatomine insects and potential animal reservoirs in Colombia. The results also confirm solid evidence of the presence of T. cruzi infection in 38 out of 71 animal species and in 14 out of 18 triatomine species studied. Among animals, the species with the highest pooled prevalence were opossums (Didelphis marsupialis) and domestic dogs (Canis lupus familiaris). Among triatomines, the highest prevalence was found in T. maculata from peridomestic ecotopes followed by $R$. prolixus and $R$. pallescens, both from sylvatic ecotopes. Further research is needed to better understand the interaction between these species, humans and parasites.

\section{Additional files}

\author{
Additional file 1. PRISMA checklist.
}

Additional file 2. Text S1. Additional text on quality assessment. Table S1. Boolean algorithms for literature search as of 5 th of April 2018. Table S2. Pooled prevalence estimates of T. cruzi infection in both triatomines and potential animal reservoirs by departments (firs administrative units) in Colombia. Table S3. Detailed data for the 18 studies chosen for potential T. cruzi reservoirs in Colombia. Table S4. Detailed data for the 28 studies chosen for Trypanosoma cruzi triatomine vectors in Colombia. Table S5. Results of point or pooled prevalence estimates (meta-analysis using random effects model) by detailed diagnostic methods for the different orders of potential Trypanosoma cruzi animal reservoirs studied in Colombia. Table S6. Results of point or pooled prevalence estimates (meta-analysis using random effects model) of $T$. cruzi infection by detailed diagnostic methods for the different orders of triatomines studied in Colombia. Table S7. Results of Egger's test for publication bias assessment for estimates of T. cruzi infection rates in animal reservoirs and triatomine vectors in Colombia. Table S8. Results of point or pooled prevalence estimates (meta-analysis using random effects model) for the different orders of potential Trypanosoma cruzi reservoirs studied in Colombia, using only high-quality reports. Table S9. Results of point or pooled prevalence estimates (meta-analysis using random effects model) of T. cruzi infection for the different orders of triatomines studied in Colombia, using only high-quality reports. Figure S1. Content quality assessment of the 39 studies used in the meta-analysis. Figure S2. Funnel plot of the $95 \% \mathrm{Cl}$ pseudo limits for the estimates of T. cruzi prevalence in animal reservoirs in Colombia.

\section{Abbreviations}

95\% Cl: 95\% confidence interval; PCR: polymerase chain reaction.

\section{Acknowledgements}

We acknowledge joint Centre funding from the UK Medical Research Council and Department for International Development. We also thank Imperial College Library for the provision of essential articles.

\section{Authors' contributions}

ERM and ZMC conceived the idea and designed the study. ERM conducted the data search, extraction and formal analyses and wrote the first draft of the paper. OC guided taxonomic evaluation and biological analyses. ZMC guided the study design, statistical analyses and paper writing. FP revised and corrected the manuscript. All authors read and approved the final manuscript.

\section{Funding}

ZMC received funding from MRC Rutherford Fund Fellow at Imperial College London, grant code MR/R024855/1. OCB is supported by COLCIENCIAS Postdoctoral fellowship 2018-2019.

\section{Availability of data and materials}

The datasets generated and analysed during the present study are available in a public repository, github.com/zmcucunuba/heterogeneity-tcruzi-review.

\section{Ethics approval and consent to participate}

Not applicable. This study is an analysis of already published aggregated data so that no ethics approval or consent to participate is required.

\section{Consent for publication}

Not applicable.

\section{Competing interests}

The authors declare that they have no competing interests.

\section{Author details}

${ }^{1}$ Facultad de Medicina, Universidad El Bosque, Bogotá, Colombia. ${ }^{2}$ Grupo de Investigación en Enfermedades Tropicales del Ejercito (GINETEJ), Bogotá, Colombia. ${ }^{3}$ Department of Infectious Disease Epidemiology, MRC Centre 
for Global Infectious Disease Analysis (MRC GIDA), Imperial College London, London, UK.

Received: 8 August 2018 Accepted: 29 May 2019

Published online: 20 June 2019

\section{References}

1. Lee BY, Bacon KM, Bottazzi ME, Hotez PJ. Global economic burden of Chagas disease: a computational simulation model. Lancet Infect Dis. 2013;13:342-8.

2. Cucunubá ZM, Okuwoga $O$, Basáñez M-G, Nouvellet P. Increased mortality attributed to Chagas disease: a systematic review and meta-analysis. Parasites Vectors. 2016:9:42.

3. Rassi A, Rassi A, Marin-Neto JA. Chagas disease. Lancet. 2010;375:1388-402.

4. Breniére SF, Waleckx E, Barnabé C. Over six thousand Trypanosoma cruzi strains classified into discrete typing units (DTUs): attempt at an inventory. PLoS Negl Trop Dis. 2016;10:e0004792.

5. Hernández C, Salazar C, Brochero H, Teherán A, Buitrago LS, Vera M, et al. Untangling the transmission dynamics of primary and secondary vectors of Trypanosoma cruzi in Colombia: parasite infection, feeding sources and discrete typing units. Parasites Vectors. 2016;9:620.

6. Guhl F, Aguilera G, Pinto N, Vergara D. Updated geographical distribution and ecoepidemiology of the triatomine fauna (Reduviidae: Triatominae) in Colombia. Biomedica. 2007;27(Suppl. 1):143-62.

7. Jansen A, Roque A. Domestic and wild mammalian reservoirs. In: Telleira J, Tibayrenc M, editors. American trypanosomiasis Chagas disease: one hundred years of research. London: Elsevier; 2010. p. 249-76.

8. WHO. Control de la enfermedad de Chagas: Segundo informe del comité de Expertos OMS. Geneva: World Health Organization; 2002. p. 117.

9. Reithinger R, Tarleton RL, Urbina JA, Kitron U, Gürtler RE. Eliminating Chagas disease: challenges and a roadmap. BMJ. 2009;338:b1283.

10. Workshop on epidemiology and social determining factors of Chagas disease: basic information for surveillance and control policy in Latin America. Mem Inst Oswaldo Cruz. 2007;102(Suppl. 1):5-10.

11. Guhl F. Enfermedad de Chagas: realidad y perspectivas. Biomédica. 2009;20:228-34

12. Brito RN, Gorla DE, Diotaiuti L, Gomes ACF, Souza RCM, Abad-Franch F. Drivers of house invasion by sylvatic Chagas disease vectors in the Amazon-Cerrado transition: a multi-year, state-wide assessment of municipality-aggregated surveillance data. PLoS Negl Trop Dis. 2017:11:e0006035.

13. Andrade DV, Gollob KJ, Dutra WO. Acute Chagas disease: new global challenges for an old neglected disease. PLoS Negl Trop Dis. 2014;8:e3010

14. Schweigmann NJ, Pietrokovsky S, Bottazzi V, Conti O, Bujas MA, Wisnivesky-Colli C. Estudio de la prevalencia de la infección por Trypanosoma cruzi en zarigüeyas (Didelphis albiventris) en Santiago del Estero, Argentina. Rev Panam Salud Pública. 1999;6:371-7.

15. Reyes M, Torres Á, Esteban L, Flórez M, Angulo VM. Risk of transmission of Chagas disease by intrusion of triatomines and wild mammals in Bucaramanga, Santander, Colombia. Biomedica. 2017;37:68-78.

16. Ramírez JD, Montilla M, Cucunubá ZM, Floréz AC, Zambrano P, Guhl F. Molecular epidemiology of human oral Chagas disease outbreaks in Colombia. PLoS Negl Trop Dis. 2013;7:e2041.

17. Ocaña-Mayorga S, Llewellyn MS, Costales JA, Miles MA, Grijalva MJ. Sex, subdivision, and domestic dispersal of Trypanosoma cruzi lineage I in southern Ecuador. PLoS Negl Trop Dis. 2010;4:e915.

18. Rassi A Jr, Rassi A, Marcondes de Rezende J. American trypanosomiasis (Chagas disease). Infect Dis Clin North Am. 2012;26:275-91.

19. Guhl F. Memorias primer taller internacional sobre control de la enfermedad de Chagas. Bogotá: Universidad de los Andes; 2005.

20. Ministerio de la Protección Social. Gestión para la vigilancia entomológica y control de la transmisión de la enfermedad de Chagas. Bogotá: Ministerio de la Protección Social; 2011.

21. Dib JC. Enfermedad de Chagas en las comunidades indígenas de la Sierra Nevada de Santa Marta. Bogotá: OPS; 2011.

22. Cucunubá ZM, Nouvellet P, Conteh L, Vera MJ, Angulo VM, Dib JC, et al. Modelling historical changes in the force-of-infection of Chagas disease to inform control and elimination programmes: application in Colombia. BMJ Glob Health. 2017;2:e000345.

23. Vallejo GA, Suárez Y, Olaya JL, Gutiérrez SA, Carranza JC. Trypanosoma rangeli: un protozoo infectivo y no patógeno para el humano que contribuye al entendimiento de la transmisión vectorial y la infección por Trypanosoma cruzi, agente causal de la enfermedad de Chagas. Rev Acad Colomb Cienc Ex Fis Nat. 2015;39:111-22.

24. Guhl F, Vallejo GA. Trypanosoma (Herpetosoma) rangeli Tejera, 1920: an updated review. Mem Inst Oswaldo Cruz. 2003:98:435-42.

25. Griemberg G, Ferrarotti NF, Svibel G, Ravelli MR, Taranto NJ, Malchiodi EL, et al. Inmunofluorescencia con Crithidia luciliae para la detección de anticuerpos anti-ADN. Imágenes atípicas y su relación con enfermedad de Chagas y leishmaniasis. Medicina (B. Aires). 2006;66:3-8.

26. Ding H, Gao Y-M, Deng Y, Lamberton PHL, Lu D-B. A systematic review and meta-analysis of the seroprevalence of Toxoplasma gondii in cats in mainland China. Parasites Vectors. 2017;10:27.

27. Schwarzer G, Carpenter JR, Rücker G. Meta-analysis with R. Freiburg: Springer; 2015

28. Barendregt JJ, Doi SA, Lee YY, Norman RE, Vos T. Meta-analysis of prevalence. J Epidemiol Community Health. 2013;67:974-8.

29. Haidich AB. Meta-analysis in medical research. Hippokratia. 2010;14:29-37.

30. Higgins JPT, Thompson SG, Deeks JJ, Altman DG. Measuring inconsistency in meta-analyses. BMJ. 2003;327:557-60.

31. Egger M, Davey Smith G, Schneider M, Minder C. Bias in meta-analysis detected by a simple, graphical test. BMJ. 1997;315:629-34.

32. Wolfenden L, Jones J, Williams CM, Finch M, Wyse RJ, Kingsland M, et al. Strategies to improve the implementation of healthy eating, physical activity and obesity prevention policies, practices or programmes within childcare services. Cochrane Database Syst Rev. 2016;10:CD011779.

33. León CM, Hernández C, Montilla M, Ramírez JD. Retrospective distribution of Trypanosoma cruzi I genotypes in Colombia. Mem Inst Oswaldo Cruz. 2015;110:387-93.

34. Jansen AM, das Chagas Xavier SC, Roque ALR. Trypanosoma cruzi transmission in the wild and its most important reservoir hosts in Brazil. Parasites Vectors. 2018;11:502

35. Jansen AM, Leon L, Machado GM, da Silva MH, Souza-Leão SM, Deane MP. Trypanosoma cruzi in the opossum Didelphis marsupialis: parasitological and serological follow-up of the acute infection. Exp Parasitol. 1991;73:249-59.

36. Hernández C, Vera MJ, Cucunubá Z, Flórez C, Cantillo O, Buitrago LS, et al. High-resolution molecular typing of Trypanosoma cruzi in 2 large outbreaks of acute Chagas disease in Colombia. J Infect Dis. 2016;214:1252-5.

37. Soto H, Tibaduiza T, Montilla M, Triana O, Suárez DC, Torres MT, et al. Investigation of vectors and reservoirs in an acute Chagas outbreak due to possible oral transmission in Aguachica, Cesar, Colombia. Cad Saude Publica. 2014;30:746-56.

38. Zuleta-Dueñas LP, López-Quiroga Á, Torres-Torres F, Castañeda-Porras O. Possible oral transmission of Chagas disease among hydrocarbons sector workers in Casanare, Colombia, 2014. Biomedica. 2017:37:218-32.

39. Xavier SC, Roque AL, Bilac D, de Araújo VA, da Costa Neto SF, Lorosa ES, et al. Distantiae transmission of Trypanosoma cruzi: a new epidemiological feature of acute Chagas disease in Brazil. PLoS Negl Trop Dis. 2014;8:e2878.

40. Urdaneta-Morales S. Chagas' disease: an emergent urban zoonosis. The caracas valley (Venezuela) as an epidemiological model. Front Public Health. 2014;2:265.

41. Diosque P, Padilla AM, Cimino RO, Cardozo RM, Negrette OS, Marco JD, et al. Chagas disease in rural areas of Chaco Province, Argentina: epidemiologic survey in humans, reservoirs, and vectors. Am J Trop Med Hyg. 2004;71:590-3.

42. Gürtler RE, Cecere MC, Lauricella MA, Cardinal MV, Kitron U, Cohen JE. Domestic dogs and cats as sources of Trypanosoma cruzi infection in rural northwestern Argentina. Parasitology. 2007;134:69-82.

43. Rocha FL, Roque ALR, Arrais RC, Santos JP, Lima VDS, Xavier SCDC, et al. Trypanosoma cruzi Tcl and Tcll transmission among wild carnivores, small mammals and dogs in a conservation unit and surrounding areas, Brazil. Parasitology. 2013;140:160-70.

44. Gürtler RE, Cécere MC, Petersen RM, Rubel DN, Schweigmann NJ. Chagas disease in north-west Argentina: association between Trypanosoma cruzi 
parasitaemia in dogs and cats and infection rates in domestic Triatoma infestans. Trans R Soc Trop Med Hyg. 1993;87:12-5.

45. Mott KE, Muniz TM, Lehman JS, Hoff R, Morrow RH, de Oliveira TS, et al. House construction, triatomine distribution, and household distribution of seroreactivity to Trypanosoma cruzi in a rural community in northeast Brazil. Am J Trop Med Hyg. 1978;27:1116-22.

46. Angulo-Silva VM, Castellanos-Domínguez YZ, Flórez-Martínez M, EstebanAdarme L, Pérez-Mancipe W, Farfán-García AE, et al. Human trypanosomiasis in the eastern plains of Colombia: new transmission scenario. Am J Trop Med Hyg. 2016;94:348-51.

47. Wilkinson GS, South JM. Life history, ecology and longevity in bats. Aging Cell. 2002;1:124-31.

48. Pinto CM, Ocaña-Mayorga S, Tapia EE, Lobos SE, Zurita AP, Aguirre-Villacís $F$, et al. Bats, trypanosomes, and triatomines in Ecuador: new insights into the diversity, transmission, and origins of Trypanosoma cruzi and Chagas disease. PLoS ONE. 2015;10:e0139999.

49. Dos Santos FCB, Lisboa CV, Xavier SCC, Dario MA, Verde R, Calouro AM, et al. Trypanosoma sp. diversity in Amazonian bats (Chiroptera; Mammalia) from Acre State, Brazil. Parasitology. 2018;145:828-37.

50. Marinkelle CJ. Prevalence of Trypanosoma cruzi-like infection of Colombian bats. Ann Trop Med Parasitol. 1982;76:125-34.

51. Rendón LM, Guhl F, Cordovez JM, Erazo D. New scenarios of Trypanosoma cruzi transmission in the Orinoco region of Colombia. Mem Inst Oswaldo Cruz. 2015;110:283-8.

52. Ramírez JD, Hernández C, Montilla M, Zambrano P, Flórez AC, Parra E, et al. First report of human Trypanosoma cruzi infection attributed to TcBat genotype. Zoonoses Public Health. 2014;61:477-9.

53. Barretto MP. Estudos sôbre reservatórios e vetores silvestres do Trypanosoma cruzi: XVII. Contribuição para o estudo dos focos naturais da tripanossomose americana, com especial referência à região nordeste do Estado de São Paulo, Brasil. Rev Soc Bras Med Trop. 1967;1:23-36.

54. Rocha FL, Roque ALR, de Lima JS, Cheida CC, Lemos FG, de Azevedo FC, et al. Trypanosoma cruzi infection in neotropical wild carnivores (Mammalia: Carnivora): at the top of the T. cruzi transmission chain. PLoS ONE. 2013:8:e67463.

55. de Noya BA, Pérez-Chacón G, Díaz-Bello Z, Dickson S, Muñoz-Calderón A, Hernández C, et al. Description of an oral Chagas disease outbreak in Venezuela, including a vertically transmitted case. Mem Inst Oswaldo Cruz. 2017;112:569-71.

56. Ministerio de Protección Social, Organización Panamerica de Salud, Instituto Nacional de Salud. Protocolo de vigilancia entomologica y control vectorial de la enfermedad de Chagas. Bogotá: Ministerio de Salud y Protección Social; 2014.

57. Guhl F, Restrepo M, Angulo VM, Antunes CMF, Campbell-Lendrum D, Davies CR. Lessons from a national survey of Chagas disease transmission risk in Colombia. Trends Parasitol. 2005:21:259-62.

58. Angulo VM, Esteban L, Luna KP. Attalea butyracea palms adjacent to housing as a source of infestation by Rhodnius prolixus (Hemiptera: Reduviidae). Biomedica. 2012;32:277-85.

59. Urbano P, Poveda C, Molina J. Effect of the physiognomy of Attalea butyracea (Arecoideae) on population density and age distribution of Rhodnius prolixus (Triatominae). Parasites Vectors. 2015;8:199.

60. Gómez-Melendro EN, Hernández C, González-Uribe C, Brochero H. First record of Triatoma maculata (Erichson, 1848) (Hemiptera: Reduviidae: Triatomini) in the Municipality of Riohacha, La Guajira_Colombia. Front Public Health. 2014;2:219

61. Cantillo-Barraza O, Garcés E, Gómez-Palacio A, Cortés LA, Pereira A, Marcet PL, et al. Eco-epidemiological study of an endemic Chagas disease region in northern Colombia reveals the importance of Triatoma maculata (Hemiptera: Reduviidae), dogs and Didelphis marsupialis in Trypanosoma cruzi maintenance. Parasites Vectors. 2015;8:482.

62. Lizano A. Índice de defecación y éxito reproductivo de Triatoma maculata (Hemiptera: Reduviidae) en condiciones de laboratorio. Rev Biol Trop. 2004:52:927-30.

63. Cantillo-Barraza O, Gómez-Palacio A, Salazar D, Mejía-Jaramillo AM, Calle J, Triana O. Distribution and ecoepidemiology of the triatomine fauna (Hemiptera: Reduviidae) in Margarita Island, Bolívar, Colombia. Biomedica. 2010;30:382-9.

64. Castro-Salas M. Aspectos ecoepidemiológicos en la transmisión de la enfermedad de Chagas en Santa Rosalia, Vichada. Bogotá: Universidad Nacional de Colombia; 2013. p. 1-101.
65. Jácome-Pinilla D, Hincapie-Peñaloza E, Ortiz MI, Ramírez JD, Guhl F, Molina J. Risks associated with dispersive nocturnal flights of sylvatic Triatominae to artificial lights in a model house in the northeastern plains of Colombia. Parasites Vectors. 2015;8:600.

66. Cantillo-Barraza O, Chaverra D, Marcet P, Arboleda-Sánchez S, TrianaChávez O. Trypanosoma cruzi transmission in a Colombian Caribbean region suggests that secondary vectors play an important epidemiological role. Parasites Vectors. 2014;7:381.

67. Zeledón R, Marín F, Calvo N, Lugo E, Valle S. Distribution and ecological aspects of Rhodnius pallescens in Costa Rica and Nicaragua and their epidemiological implications. Mem Inst Oswaldo Cruz. 2006;101:75-9.

68. Hurtado LA, Calzada JE, Pineda V, González K, Santamaría AM, Cáceres $L$, et al. Knowledge and risk factors related to Chagas' disease in two Panamanian communities where Rhodnius pallescens is the main vector. Biomedica. 2014;34:260-70.

69. Saldaña A, Santamaría AM, Pineda V, Vásquez V, Gottdenker NL, Calzada JE. A darker chromatic variation of Rhodnius pallescens infected by specific genetic groups of Trypanosoma rangeli and Trypanosoma cruzi from Panama. Parasites Vectors. 2018;11:423.

70. Sandoval CM, Ortiz N, Jaimes D, Lorosa E, Galvão C, Rodriguez O, et al. Feeding behaviour of Belminus ferroae (Hemiptera: Reduviidae), a predaceous Triatominae colonizing rural houses in Norte de Santander, Colombia. Med Vet Entomol. 2010;24:124-31.

71. D'Alessandro A, Barreto P, Saravia N, Barreto M. Epidemiology of Trypanosoma cruzi in the oriental plains of Colombia. Am J Trop Med Hyg. 1984;33:1084-95.

72. Nouvellet P, Cucunubá ZM, Gourbière S. Ecology, evolution and control of Chagas disease: a century of neglected modelling and a promising future. Adv Parasitol. 2015;87:135-91.

73. Erazo D, Cordovez J, Cabrera C, Calzada JE, Saldaña A, Gottdenker NL. Modelling the influence of host community composition in a sylvatic Trypanosoma cruzi system. Parasitology. 2017;144:1881-9.

74. Orellana-Halkyer N, Arriaza-Torres B. Enfermedad de Chagas en poblaciones prehistóricas del norte de Chile. Rev Chil Hist Nat. 2010;83:531-41.

75. Sangenis LHC, Nielebock MAP, Santos CD, Silva MC, Bento GM. Chagas disease transmission by consumption of game meat: systematic review. Rev Bras Epidemiol. 2016;19:803-11.

76. Minuzzi-Souza TTC, Nitz N, Cuba CAC, Hagström L, Hecht MM, Santana C, et al. Surveillance of vector-borne pathogens under imperfect detection: lessons from Chagas disease risk (mis)measurement. Sci Rep. 2018:8:151.

77. Vásquez C, Robledo S, Calle J, Triana O. Identification of new epidemiological scenarios for Chagas disease in the Momposina region, North of Colombia. Biomedica. 2013;33:526-37.

78. Jaimes-Dueñez J, Triana-Chávez O, Cantillo-Barraza O, Hernández C, Ramírez JD, Góngora-Orjuela A. Molecular and serological detection of Trypanosoma cruzi in dogs (Canis lupus familiaris) suggests potential transmission risk in areas of recent acute Chagas disease outbreaks in Colombia. Prev Vet Med. 2017;141:1-6.

79. Wolff M, Castillo D, Uribe J, Arboleda JJ. American trypanosomiasis: determination of epidemiologic transmission risk in Amalfi, Antioquia, Colombia. latreia. 2001;14:111-21.

80. Escalante ME, Gomez D, Silvera LA, Sánchez G, Venegas J. Detection of high percentage of Trypanosoma cruzi infection, the etiologic agent of Chagas disease, in wild populations of Colombian Caribbean triatomines. Acta Parasitol. 2015;60:315-21.

81. Parra-Henao GJ, Florez M, Ángulo VM, Red Chagas Colombia, editores. Vigilancia de Triatominae (Hemiptera: Reduviridae) en Colombia. In: Memorias del Curso de Capacitación Métodos Básicos en Epidemiología y Redacción Científica. Bogotá: Sic Editorial; 2015.

82. Cortéz LA, Suárez HA. Triatomines (Reduviidae: Triatominae) in a Chagas disease focus in Talaigua Nuevo (Bolívar, Colombia). Biomedica. 2005;25:568-74.

83. Manrique-Abril D, Manrique-Abril F, Lorca MH, Ospina JD. Prevalence of antibodies for Trypanosoma cruzi in canines from two endemic municipalities of Boyacá. Rev MVZ Córdoba. 2012;17:2916-23.

84. Ramírez JD, Turriago B, Tapia-Calle G, Guhl F. Understanding the role of dogs (Canis lupus familiaris) in the transmission dynamics of Trypanosoma cruzi genotypes in Colombia. Vet Parasitol. 2013;196:216-9.

85. Ramírez JD, Tapia-Calle G, Muñoz-Cruz G, Poveda C, Rendón LM, Hincapié E, et al. Trypanosome species in Neotropical bats: biological, evolutionary and epidemiological implications. Infect Genet Evol. 2014;22:250-6. 
86. D'Alessandro A, Wells EA. Trypanosome infections in the family Cervidae. Trans R Soc Trop Med Hyg. 1971;65:845.

87. Sandoval CM, Duarte R, Gutíerrez R, Rocha DDS, Angulo VM, Esteban L, et al. Feeding sources and natural infection of Belminus herreri (Hemiptera, Reduviidae, Triatominae) from dwellings in Cesar, Colombia. Mem Inst Oswaldo Cruz. 2004;99:137-40.

88. Montilla M, Soto H, Parra E, Torres M, Carrillo P, Lugo L, et al. Infestation by triatomine bugs in indigenous communities of Valledupar, Colombia. Rev Saude Publica. 2011:45:773-80.

89. Parra GJ, Restrepo Isaza M, Restrepo BN, de Dios Domínguez J. Estudio de tripanosomiasis americana en dos poblados indígenas de la Sierra Nevada de Santa Marta, Colombia. CES Med. 2004;18:43-50.

90. Parra-Henao G, Angulo V, Jaramillo N, Restrepo M. Triatominos (Hemiptera: Reduviidae) de la Sierra Nevada de Santa Marta, Colombia. Aspectos epidemiológicos, entomológicos y de distribución. CES Med. 2009;23:17-26.

91. Mejía-Jaramillo AM, Agudelo-Uribe LA, Dib JC, Ortiz S, Solari A, TrianaChávez O. Genotyping of Trypanosoma cruzi in a hyper-endemic area of Colombia reveals an overlap among domestic and sylvatic cycles of Chagas disease. Parasites Vectors. 2014;7:108.

92. Parra-Henao G, Angulo VM, Osorio L, Jaramillo-O N. Geographic distribution and ecology of Triatoma dimidiata (Hemiptera: Reduviidae) in Colombia. J Med Entomol. 2016;53:122-9.

93. Marinkelle CJ. The prevalence of Trypanosoma cruzi infection in Colombia monkey and marmosets. Ann Trop Med Parasitol. 1982;76:121-4.
94. Delgado-Sarmiento E, Herrera-Sepúlveda M-T, Pavía P, Pérez-Torres J, Cuervo CL. Trypanosoma cruzi infection in the heart of Colombian wild bats. Int J Infect Dis. 2016;45:356-7.

95. Peña-García VH, Gómez-Palacio AM, Triana-Chávez O, Mejía-Jaramillo AM. Eco-epidemiology of Chagas disease in an endemic area of Colombia: risk factor estimation, Trypanosoma cruzi characterization and identification of blood-meal sources in bugs. Am J Trop Med Hyg 2014;91:1116-24

96. Dib J, Barnabe C, Tibayrenc M, Triana O. Incrimination of Eratyrus cuspidatus (Stal) in the transmission of Chagas' disease by molecular epidemiology analysis of Trypanosoma cruzi isolates from a geographically restricted area in the north of Colombia. Acta Trop. 2009;111:237-42.

97. Salazar DA, Calle J. Caracterización ecoepidemiológica de Rhodnius pallescens en la palma Attalea butyracea en la región Momposina (Colombia). Actual Biol. 2003;25:31-8.

98. Travi BL, Jaramillo C, Montoya J, Segura I, Zea A, Goncalves A, et al. Didelphis marsupialis, an important reservoir of Trypanosoma (Schizotrypanum) cruzi and Leishmania (Leishmania) chagasi in Colombia. Am J Trop Med Hyg. 1994;50:557-65.

\section{Publisher's Note}

Springer Nature remains neutral with regard to jurisdictional claims in published maps and institutional affiliations.
Ready to submit your research? Choose BMC and benefit from:

- fast, convenient online submission

- thorough peer review by experienced researchers in your field

- rapid publication on acceptance

- support for research data, including large and complex data types

- gold Open Access which fosters wider collaboration and increased citations

- maximum visibility for your research: over $100 \mathrm{M}$ website views per year

At BMC, research is always in progress.

Learn more biomedcentral.com/submissions 